\title{
Spatial Pattern of Multi-dimensional Regional Disparities in the Level of Socio-economic Development in West Bengal: A Geographical Analysis
}

\author{
Suranjan Majumder* \\ Department of Geography \& Applied Geography, University of North Bengal, Darjeeling, \\ West Bengal, India
}

Received 27 July 2021/Revised 13 October 2021/Accepted 27 November 2021/Published 20 December 2021

\begin{abstract}
Micro-level spatial analysis of the different phenomenon duly associated with human development and also with the wellbeing of a nation. The study is a heart-core attempt to examine the inter-block regional disparity and development by constructing a multidimensional approach-based index. The study used thirty-four sub-dimensional variables under the five dimensions, including health, education, economy, socio-demography, and transport. The article used the data of the district statistical handbook of 2013 and census data of 2011. The empirical results of the study confirm the existence of huge inter-regional disparity on multi-dimensional developmental aspects, which drastically hampers the allround growth and socio-economic development of Jalpaiguri Administrative Dvision (JAD) of West Bengal. The blocks of Khairabari, Darjeeling-Pulbazar, Rngli-rangit, Mirik, Kurseong, Kalimpong I \& II are found to be high regional imbalances in the development of education, health, employment, and economy. The study also helps to identify the most backward blocks. It confirms the huge inter-block/district disparities in West Bengal. The study argued that the low developed and high disparities blocks require special attention from policymakers in order to the improvement of overall socio-economic development of the study area.
\end{abstract}

Keywords: Jalpaiguri Administrative Division; Multi-dimensonal approach; Regional disparity; Regional imbalances; Socio-economic development

\section{Introduction}

Regional disparities at the micro-level hamper the developmental process and minimize the scope of national growth on large (Braveman, 2014; Ohlan, 2013). Regional disparities have been closely linked with the development and influence the factors of economy and policy formation (Novkovska, 2017). The work of Novkovska (2017) found that hidden economic growth substantially influences the development and stretches the interregional gap of developmental factors. Regional disparity defines as an unequal spatial

*Corresponding author.

Email address : suranjanmajumder1996@gmail.com (Suranjan Majumder) 
distribution of social, economic, natural, and material resources across the nation, states, district, or local administrative units (like community development blocks, villages, and municipalities). Disparity measure is vital to identify a backward region in relation to the neighboring region, which helps to reform the way of planning (Das, 2018). Development, especially sustainable and equitable development, is the key concern of modern policymaking and the research community. Because the sustainable distribution of resources inclusively improved the quality of life of the population. The disparities of developmental components demarcate an invisible line between highly developed, moderate developed, less developed, and underdeveloped regions. Majorly uneconomic growth categorically hamper the region's overall development status and the people's quality of life and wellbeing (Mishra \& Gaikward, 1979). Banerjee (1992) found that the rural areas of India are typically suffering from the incidence of regional imbalances in socio-economic development.

Das (2018) indicates that inter-district variation of human development indicators was significant in West Bengal. Similarly, in West Bengal, high inter-district disparity existed in terms of Gross Domestic Product and Per Capita Income (Dey, 2015). Most of the district has less developed in socio-physical, economic, demographic, and infrastructural categories, which impede the overall growth (Dey, 2015). Most of the northern part of West Bengal was less developed (Das, 2018). The district Alipurduar has less developed in terms of social, economic, transport, education, and health (Sam \& Chakma, 2016). It is obvious that the less developed notion of a district is reflected in the development of villages and blocks. Nevertheless, the studies majorly showcase the condition of the district and ignore micro-units. So, the present study is conducted to reveal the block level spatial pattern of disparity and stage of development. Additionally, to formulate a constructive way to analyze the regional disparities. The main objective of the study is to examine the inter-block disparity as well as development in multiple indications. Further, the study provides a brief outline of the socio-economic development of selected parts of the study area. In the emerging world where development is a foremost notion to compete against different socioeconomic inequalities (Sultana \& Aktar, 2016). The study actually helps to devise the notion in consideration by applying the idea of micro-level developmental perspective. The study categorically identify the loopholes and existing inequality in multiple socio-economic indicators, that broadened he targeted regional policy framework for inclusive micro-level regional development and also devise methodology to access the multiple deprivations in a single framework. The upcoming part of introduction provide an outlook about Multi- 
dimensional disparity and its importance in the assessment of regional development perspective.

Development and disparity is a dynamic aspects that should always be measure in multidimensional scale (Ohlan, 2013; Sharma, 2012; Talmaciu, 2014). The concept of analyzing the multi-dimensional aspects is widely practiced by United Nations Developmental Program (UNDP) and Oxford Poverty \& Human Development Initiative (OPHI) through Multidimensional Poverty Index. The principal aim of constructing a multidimensional index is to combine a series of variables in a single platform. For example, English Indices of Deprivation combines seven domains (income, employment, health, education, crime, housing and service, and living environment) with equal weights. Braveman (2014) describes health disparity as the unsystematic distribution of health resources that greatly influence socio-economic development, cognitive ability, physical health, and mental wellbeing (Braverman, 2014). The multi-dimensional disparity also refers to the difference in resource distribution and uneven socio-economic development.

Different aspects of human development, regional development is an interactive part of human wellbeing and quality of life (Dholakia, 2003; Mishra et al., 1979). Further, the inter-regional disparity of social, economic, and infrastructural indicators is a common phenomenon across the world. But a developing country like India is facing lots of challenges to minimize inter-regional inequality due to social, economic, agricultural, income, heath, education, and infrastructural disparity (Das, 2018). The micro-level disparity, substantially caused by physiographic unsuitability, climate, historical legacy, socio-cultural diversity, and political instability, also influenced the distribution of natural and material resources (Kwatiah, 2021). In view of the above discussions, the study's main objective is to examine the inter-block disparity as well as development in multiple indications. Further, the study provides a brief outline of the socio-economic development of selected parts of the study area.

Table 1. Basic demographic attributes of Community Development Blocks (CD Blocks) of Jalpaiguri Administrative Division, West Bengal (Census of India, 2011a,b,c)

\begin{tabular}{lccccccc}
\hline \multicolumn{1}{c}{ Blocks } & $\begin{array}{c}\text { Share of } \\
\text { Rural } \\
\text { Population }\end{array}$ & $\begin{array}{c}\text { Female Work } \\
\text { Participation }\end{array}$ & $\begin{array}{c}\text { Share of SC } \\
\text { Population }\end{array}$ & $\begin{array}{c}\text { Share of ST } \\
\text { Population }\end{array}$ & $\begin{array}{c}\text { Total } \\
\text { Literacy }\end{array}$ & $\begin{array}{c}\text { Gap in } \\
\text { male- } \\
\text { female } \\
\text { literacy }\end{array}$ & $\begin{array}{c}\text { Sex } \\
\text { Ratio }\end{array}$ \\
\hline $\begin{array}{l}\text { Darjeeling District } \\
\begin{array}{l}\text { Darjeeling- } \\
\text { phulbazar }\end{array}\end{array}$ & 82.84 & 33.21 & 4.68 & 28.75 & 80.59 & 13.27 & 989 \\
$\begin{array}{l}\text { Rangli-Rangit } \\
\text { Continued }\end{array}$ & 100.00 & 28.68 & 5.55 & 33.07 & 80.50 & 14.30 & 1002 \\
\hline
\end{tabular}




\begin{tabular}{|c|c|c|c|c|c|c|c|}
\hline Blocks & $\begin{array}{c}\text { Share of } \\
\text { Rural } \\
\text { Population }\end{array}$ & $\begin{array}{l}\text { Female Work } \\
\text { Participation }\end{array}$ & $\begin{array}{l}\text { Share of SC } \\
\text { Population }\end{array}$ & $\begin{array}{l}\text { Share of ST } \\
\text { Population }\end{array}$ & $\begin{array}{c}\text { Total } \\
\text { Literacy }\end{array}$ & $\begin{array}{c}\text { Gap in } \\
\text { male- } \\
\text { female } \\
\text { literacy }\end{array}$ & $\begin{array}{c}\text { Sex } \\
\text { Ratio }\end{array}$ \\
\hline $\begin{array}{l}\text { Sukhiapokhri- } \\
\text { jorebunglow }\end{array}$ & 76.32 & 27.40 & 5.43 & 29.62 & 82.21 & 15.26 & 1019 \\
\hline Mirik & 100.00 & 30.03 & 7.80 & 30.79 & 80.84 & 15.20 & 982 \\
\hline Kurseong & 84.69 & 27.99 & 7.66 & 32.34 & 79.59 & 15.42 & 1006 \\
\hline Matigara & 68.73 & 21.27 & 36.02 & 18.06 & 71.94 & 15.92 & 953 \\
\hline Naxalbari & 59.04 & 22.64 & 30.46 & 29.58 & 69.02 & 16.90 & 946 \\
\hline Phansidewa & 100.00 & 23.77 & 29.68 & 30.61 & 64.46 & 16.57 & 972 \\
\hline Khairabari & 89.15 & 24.75 & 53.25 & 21.71 & 65.82 & 18.39 & 962 \\
\hline \multicolumn{8}{|c|}{ Kalimpong District } \\
\hline Kalimpong-I & 90.92 & 27.03 & 6.51 & 34.81 & 80.84 & 10.58 & 980 \\
\hline Kalimpong-II & 100.00 & 23.05 & 2.93 & 37.07 & 79.68 & 12.21 & 935 \\
\hline Gorubathan & 100.00 & 30.19 & 6.64 & 23.60 & 76.88 & 14.98 & 953 \\
\hline \multicolumn{8}{|c|}{ Cooch Behar District } \\
\hline Haldabari & 100.00 & 18.06 & 61.18 & 0.30 & 69.22 & 13.15 & 967 \\
\hline Mekhliganj & 97.11 & 24.19 & 72.86 & 1.25 & 69.03 & 15.53 & 939 \\
\hline Mathabhanga-I & 100.00 & 29.85 & 68.77 & 0.06 & 71.51 & 15.12 & 940 \\
\hline Mathabhanga-II & 100.00 & 20.33 & 64.92 & 1.31 & 72.68 & 13.85 & 942 \\
\hline Coochbehar-I & 89.81 & 23.36 & 42.22 & 0.39 & 75.44 & 12.27 & 942 \\
\hline Coochbehar-II & 84.30 & 15.25 & 48.10 & 1.11 & 80.48 & 11.36 & 915 \\
\hline Tufanganj-I & 97.85 & 20.19 & 45.85 & 0.15 & 73.64 & 12.62 & 936 \\
\hline Tufanganj-II & 97.07 & 20.21 & 54.77 & 2.18 & 75.56 & 13.25 & 941 \\
\hline Dinhata-I & 98.47 & 19.67 & 44.23 & 0.41 & 73.05 & 11.50 & 939 \\
\hline Dinhata-II & 100.00 & 17.82 & 43.78 & 0.51 & 72.33 & 11.99 & 927 \\
\hline Sitai & 100.00 & 31.77 & 66.09 & 0.19 & 62.79 & 12.96 & 970 \\
\hline Sitalkuchi & 100.00 & 22.90 & 54.50 & 0.14 & 70.34 & 13.62 & 966 \\
\hline \multicolumn{8}{|c|}{ Alipurduar District } \\
\hline $\begin{array}{l}\text { Madarihat- } \\
\text { Birpara }\end{array}$ & 93.19 & 29.56 & 13.50 & 40.47 & 66.89 & 16.82 & 990 \\
\hline Kalchini & 70.97 & 29.69 & 10.12 & 52.37 & 65.32 & 18.89 & 928 \\
\hline Kumargram & 87.20 & 25.97 & 35.96 & 34.09 & 69.79 & 14.07 & 946 \\
\hline Alipurduar-I & 74.11 & 28.37 & 55.88 & 21.71 & 72.26 & 13.91 & 948 \\
\hline Alipurduar-II & 93.76 & 21.39 & 43.09 & 19.03 & 75.29 & 12.00 & 941 \\
\hline Falakata & 83.98 & 20.58 & 44.11 & 17.01 & 70.56 & 13.67 & 943 \\
\hline \multicolumn{8}{|c|}{ Jalpaiguri District } \\
\hline Rajganj & 51.01 & 20.52 & 47.75 & 6.92 & 72.62 & 13.83 & 935 \\
\hline Mal & 91.93 & 25.07 & 26.73 & 36.73 & 65.42 & 16.44 & 973 \\
\hline Matiali & 87.13 & 33.98 & 14.73 & 48.40 & 65.48 & 21.19 & 955 \\
\hline Nagrakata & 100.00 & 29.05 & 13.84 & 49.16 & 61.27 & 18.58 & 986 \\
\hline Dhupguri & 91.62 & 27.26 & 48.96 & 20.30 & 69.23 & 16.29 & 970 \\
\hline Maynaguri & 88.46 & 16.11 & 75.15 & 1.41 & 74.19 & 14.06 & 935 \\
\hline Jalpaiguri & 80.94 & 26.60 & 61.90 & 7.15 & 72.55 & 14.56 & 948 \\
\hline $\begin{array}{l}\text { Mean Total } \\
\text { (JAD) }\end{array}$ & 89.48 & 24.80 & 36.64 & 19.26 & 72.41 & 14.61 & 957 \\
\hline
\end{tabular}

\section{Methods}

\subsection{Study Area}

The proposed study measured the spatial pattern of micro-regional disparity and development perspective of Jalpaiguri Administrative Division (JAD), one of the least developed parts of West Bengal. It lies on the foothills of the Himalayas, and the major part of the JAD is drained by several small rivers and tributaries of river Ganga and Brahmaputra like, Tista, Mahanada, Jaldhaka, and Karala. The river Tista originated from Sikkim Himalaya, flows southwards. After entering West Bengal, it cut down the JAD into two parts. 
The left bank is popularly known as Dooars, and the right bank is known as Tarai. Moreover, the major portion of JAD's economy is fed up by the tourism industry's revenue. It is a famous tourist destination (Darjeeling, Kalimpong, Mirik, Dooars and so on), mainly famous for hill stations, dense forests, and wildlife. The JAD shares international boundaries with Bhutan in the north, Bangladesh in the south, and Nepal in the West. The previous studies demonstrated that the population of the region is lived with the least socio-economic development and low capacity of livelihood diversification (Barman, 2020; Sam \& Chakma, 2016; Sarkar, 2017). Moreover, the nature of deprivations is similar to that of the other region of India. However, limited research has been conducted to depict the micro-level (interblock) scenario, which is an important criterion for policy formation.

Presently, JAD is comprised of five districts, i.e., Darjeeling (9 blocks), Kalimpong (3 blocks), Jalpaiguri (7 blocks), Alipurduar (6 blocks), and Cooch Behar (12 blocks). In 2014 the Alipurduar district was separated from Jalpaiguri, and in 2017 the Kalimpong district was separated from Darjeeling district. The demographic attributes and location of 37 blocks illustrate in Table 1 and Figure. 1. The JAD has a geographical area of about 13292 sq. km (Census of India, 2011a,b,c), covering about 14.98 percent area of West Bengal, which predominantly rural by nature. According to the 2011 census, 12 blocks are completely rural by nature, whereas the rest of the blocks comprised more than half of the population resided in rural areas (Table 1). The population density is 957 (lower than the state population density of 1029 in 2011). The Scheduled Tribes and Scheduled Castes groups (the most marginalized and backward communities in India and West Bengal) are forming the demographic majority in the region (Table 1). As per the 2011 Census, the region has a literacy rate of about 72.41 percent, which is lower than the state average literacy rate of 77.08 percent. In addition, the gender gap in literacy of JAD is recorded as 14.61, which is much higher than the state, i.e., 11.51. Around 20 percent of people of JAD are living below the poverty line. Here, 22.5 percent population from Cooch Behar, 22.1 percent from Jalpaiguri, and 14.7 percent population from Darjeeling belong to the below poverty line (Bhandari \& Chakraborty, 2015). It indicates that the people of JAD are regularly countered several vulnerabilities to run their livelihood and to facing difficulties in access of the basic necessary items for quality life, namely, quality education, earning, food security, and health care facilities. 

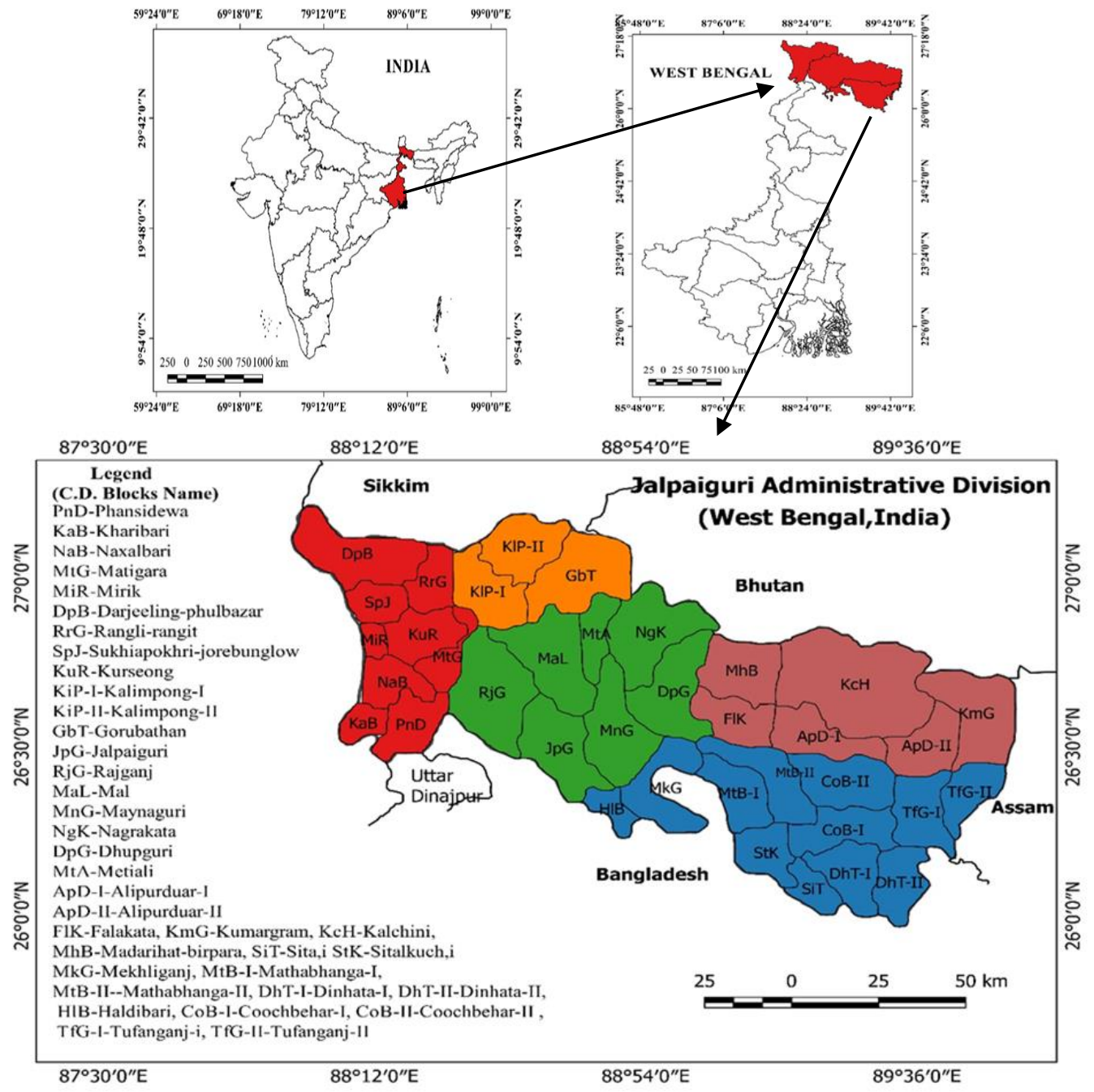

Figure 1. Location map of the study area with approaching the spatiality of Community Development Blocks of Jalpaiguri Administrative Division (JAD)

\subsection{Data Source}

The study is a definite attempt to identify the spatial pattern of regional imbalances, examine the aspects of micro-level regional development. For this purpose, I am using the data of the District Census Handbook (Part-XII, A) published by the Directorate of Census Operations and the District Statistical Handbook published by the Bureau of Applied Economics \& Statistics under the Department of Statistics \& Program Implementation of Government of West Bengal. In addition to these, the study also used information collected from the National family and health survey (NFHS) $4 \& 5$. The NFHS-4 (2015-2016) and NFHS-5 (2019-2020) a nation-based cross-sectional surveys on acquiring household-level information. 


\subsection{Selection of Indicators}

Multi-dimensional indicator selection produces a comprehensive summary of various developmental aspects of a region. Likewise, social indicators variably represent the social growth of a region (Kumar \& Rani, 2019). Drewnowski (1972) indicates to use quantifiable and measurable variables to understand the inheritance scenario of socio-economic wellbeing and needs of the people altogether. The indicators also ascertain the developmental perspective of a region (Ohlan, 2013).

In the study, selected five dimensions, i.e., Socio-demography, Health, Education, Employment and economy, transport. The five dimensions included thirty-four subdimension variables (Table 2). The selected indicators may be positively or negatively influence the developmental process of a region. For example, increasing road length, family welfare centers, hospitals positively stimulate the regions development and helps in achieving the wellbeing targets of the population. In contrast, high population density, a pupil-teacher ratio at a different level of schooling negatively triggered the development. To comprehend the inter-block spatial pattern of multi-criteria-based disparities and developmental stages of the Jalpaiguri administrative division, selected indicators (for the latest and availability of data) summarizes in Table 2.

Table 2. Dimensions and sub-dimension of multi-dimensional regional disparity and development

\begin{tabular}{|c|c|c|c|c|}
\hline Dimensions & $\begin{array}{c}\text { Sub- } \\
\text { dimensions }\end{array}$ & Description of sub-dimensions & $\begin{array}{l}\text { Conjectural } \\
\text { relation with } \\
\text { development } \\
*\end{array}$ & Adopted from \\
\hline \multirow[t]{6}{*}{$\begin{array}{l}\text { Education } \\
\text { [EDU] }\end{array}$} & $\begin{array}{l}\text { Primary Scholl } \\
\text { (PS) }\end{array}$ & $\begin{array}{c}\text { Number of primary school per } 500 \\
\text { population }\end{array}$ & {$[+]$} & $\begin{array}{c}\text { Bose et al. } \\
\text { (2020); Ohlan, } \\
\text { (2013) }\end{array}$ \\
\hline & $\begin{array}{l}\text { Middle school } \\
\text { (MS) }\end{array}$ & $\begin{array}{c}\text { Number of middle school per } 1500 \\
\text { population }\end{array}$ & {$[+]$} & $\begin{array}{l}\text { Bose et al. } \\
\quad(2020)\end{array}$ \\
\hline & $\begin{array}{l}\text { Secondary } \\
\text { school (SS) }\end{array}$ & $\begin{array}{l}\text { Number of secondary school per } \\
1500 \text { population }\end{array}$ & {$[+]$} & $\begin{array}{c}\text { Bose et al. } \\
\text { (2020); Sultana } \\
\& A k t a r(2016)\end{array}$ \\
\hline & $\begin{array}{l}\text { Higher } \\
\text { secondary } \\
\text { (HS) }\end{array}$ & $\begin{array}{l}\text { Number of higher secondary } \\
\text { school per } 1500 \text { population }\end{array}$ & {$[+]$} & $\begin{array}{l}\text { Bose et al. } \\
\text { (2020); Sultana } \\
\text { \& Aktar (2016) }\end{array}$ \\
\hline & $\begin{array}{l}\text { Special school } \\
\quad(\text { SNS })\end{array}$ & $\begin{array}{c}\text { Number of special school per } 500 \\
\text { population }\end{array}$ & {$[+]$} & Barman (2020) \\
\hline & $\begin{array}{l}\text { Pupil-teacher } \\
\text { ratio at } \\
\text { primary school }\end{array}$ & $\begin{array}{c}\text { Ratio of teacher-student at primary } \\
\text { school }\end{array}$ & {$[-]$} & - \\
\hline
\end{tabular}


(PTR $\mathrm{PS})$

Pupil-teacher

ratio at middle

(PTR $\mathrm{MS}$ )

Pupil-teacher ratio at secondary

school (PTR SS $_{\text {) }}$

Pupil-teacher ratio at higher

secondary

school

$\left(\mathrm{PTR}_{\mathrm{HS}}\right)$

Pupil-teacher

ratio at special school

(PTR $\left.{ }_{\text {SNS }}\right)$

Total literacy

(TL)

Female literacy (FL)

Total rural

female literacy

(TFRL)
Socio-

demography

[SODEM]

Total

population

(TP)

Population density (DEN)

Electricity

(EL)

Drinking water

(DW)

Fair price

shops (FPS)

Health

[HEL]

Hospitals (HP) school

Ratio of teacher-student at middle school

$[-]$

$[-]$ secondary school

Ratio of teacher-student at higher secondary school

$[-]$

$[-]$

Ratio of teacher-student at special school

Percentage of Total literate population to total population (above 7 years age)

Percentage of Female literate population to total female population(above 7 years age)

Percentage of Rural female literacy to total rural female population(above 7 years age) Total population of the block

Number of people living in each unit of area (per square kilometre)

[-] Sharma (2012); Sultana \&Aktar, (2016)

Doctors (DT)

Beds (BD)

Family welfare centre (FWC)

Child

Mortality
[+] Chotia \& Rao, (2015); Sharma, (2012);Sultana \&Aktar (2016)

[+] Sultana \& Aktar

Percentage of mouza having drinking water facilities to total mouza in a block

Number of fair price shops per 5000 population

Percentage of mouza having full electricity facilities to total mouza in a block

(2016)

[+] Barman (2020)

[+] Chotia \& Rao (2015)

[+] Bose et al. 2020

[+] Bose et al. (2020); Chotia \& Rao, (2015)

[+] Barman (2020)

[-] $\quad$ Barman (2020) per 5000 population Mortality rate under 5 year age

Number of beds in government hospital per 1000 population
Number of Family welfare centre 
(CM5)

\begin{tabular}{|c|c|c|c|c|}
\hline & $\begin{array}{l}\text { Cultivators } \\
\quad \text { (CL) }\end{array}$ & $\begin{array}{l}\text { Proportion of cultivators to the } \\
\text { total workers }\end{array}$ & {$[-]$} & $\begin{array}{l}\text { Sultana \& Aktar, } \\
\quad \text { (2016) }\end{array}$ \\
\hline \multirow{7}{*}{$\begin{array}{l}\text { Employment } \\
\text { and } \\
\text { Economy } \\
{[\text { EMECO] }}\end{array}$} & $\begin{array}{l}\text { Agricultural } \\
\text { labour (AL) }\end{array}$ & $\begin{array}{l}\text { Proportion of Agricultural labour } \\
\text { to the total workers }\end{array}$ & {$[-]$} & $\begin{array}{l}\text { Sultana \& Aktar } \\
\quad(2016)\end{array}$ \\
\hline & $\begin{array}{c}\text { Household } \\
\text { workers (HW) }\end{array}$ & $\begin{array}{l}\text { Proportion of Household workers } \\
\text { to the total workers }\end{array}$ & {$[+]$} & - \\
\hline & $\begin{array}{l}\text { Other workers } \\
\text { (OW) }\end{array}$ & $\begin{array}{l}\text { Proportion of Other workers to the } \\
\text { total workers }\end{array}$ & {$[+]$} & - \\
\hline & $\begin{array}{l}\text { Main worker } \\
\text { (MW) }\end{array}$ & $\begin{array}{l}\text { Percentage of workers who } \\
\text { engaged in work more than } 183 \\
\text { days in a year }\end{array}$ & {$[+]$} & Barman (2020) \\
\hline & $\begin{array}{l}\text { Marginal } \\
\text { worker } \\
\text { (MARW) }\end{array}$ & $\begin{array}{l}\text { Percentage of workers who } \\
\text { engaged in work less than } 183 \\
\text { days in a year }\end{array}$ & {$[-]$} & - \\
\hline & $\begin{array}{l}\text { Work } \\
\text { participation } \\
\text { rate (WPR) }\end{array}$ & $\begin{array}{l}\text { Ratio of working population to the } \\
\text { total population }\end{array}$ & {$[+]$} & Barman (2020) \\
\hline & Bank (BAN) & $\begin{array}{l}\text { Proportion of population served by } \\
\text { each bank }\end{array}$ & {$[-]$} & Sharma (2012) \\
\hline \multirow[t]{3}{*}{$\begin{array}{l}\text { Transport } \\
\text { [TRANS] }\end{array}$} & $\begin{array}{l}\text { Road density } \\
\text { (RD) }\end{array}$ & Length of road per unit area & {$[+]$} & $\begin{array}{l}\text { Chotia \& Rao, } \\
\text { (2015);Sharma, } \\
\text { (2012) }\end{array}$ \\
\hline & $\begin{array}{l}\text { Bus routes } \\
\text { (BR) }\end{array}$ & Number of originating point of bus & {$[+]$} & Barman, (2020) \\
\hline & $\begin{array}{c}\text { Railway } \\
\text { station (RS) }\end{array}$ & Distance of nearest railway station & {$[-]$} & $\begin{array}{l}\text { Chotia \& Rao, } \\
\text { (2015) }\end{array}$ \\
\hline
\end{tabular}

Note: Parentheses represent the symbol of selected dimensions and sub-dimensions; *the conjectural relation assuming in increasing trend, the adopted variables essentially modified as per the requirement of the study and availability of block level data.

\subsection{Data Analysis}

There is no universal methodology to examine the disparity and development of a region. The different studies used different methods and included diversified variables to measure the extent of regional disparity. Further, most used methods included weighted and unweight Aggregation methods, factor analysis, Principle Component Analysis, Ranking aggregation, Monetary index, Wroclaw taxonomic method (Kumar \& Rani, 2019; Ohlan, 2013). 


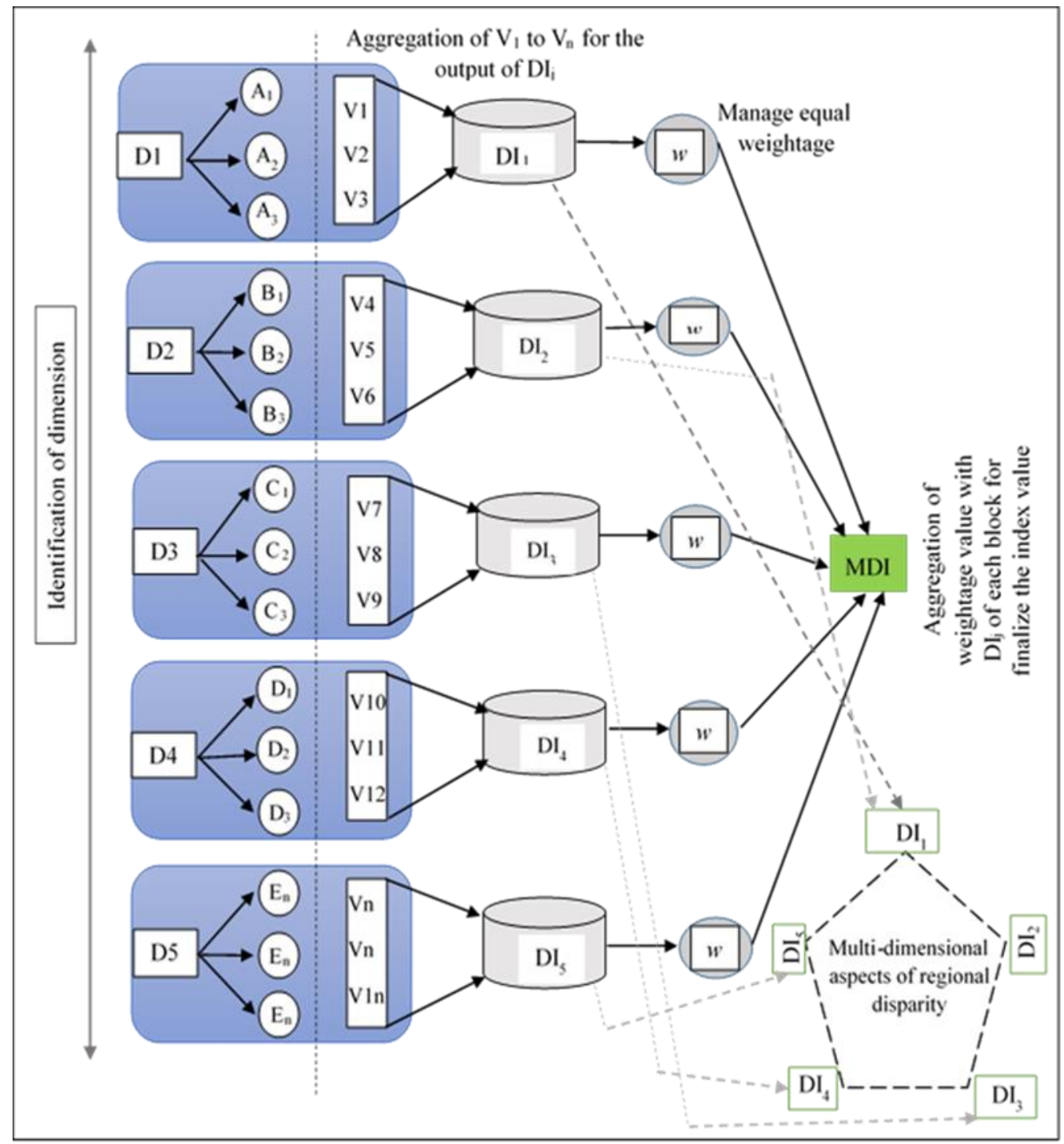

Figure 2. Schematic presentation of tier wise methodology for the final output of multidimensional approach based regional disparity measurement

The critical stage of the index computation involved identifying the dimensions and associated variables. The task has been completed through the extensive literature review and availability of data at the block level. The computed indices are simply prepared by the aggregation of subcomponents with equal weightage of each variable with the same importance. The proposed method provides an applicable methodology in measuring the inter-region disparity.

The steps of multi-dimensional disparity index presented in the schematic diagram and flow chart of Figure 2 and Figure 3. In the first two step, it mainly involved in the identification of variables which has been recognized the multi-criteria based disparity 
measurement. In the third stapes, employed the data standardization methods by using the Eq. $1 \& 2$. The data standardization is necessary because not each variable measure with the same unit. For example, population density measures per square kilometer, literacy rate measure through percentage, whereas population, pupil-teacher ratio is unitless. The data standardization procedure was first applied by UNDP in the construction of the Human Development Index (Banu \& Biswas, 2011). Later, it is widely used in a different fields. However, the UNDPs equation of normalization does not adhere to the relation of variables with the index. Later Adu et al. (2013) in the study applied two equations based on the probable relation, which accentuates the result. As per Adu et al. (2013), Eq. 1 has employed when a sub-dimensional variable is positively related to development, and Eq. 2 is employed when variables negatively influence the developmental process. Then, in the fourth stapes, computed disparity index $\left(\mathrm{DI}_{\mathrm{j}}\right)$ of five dimensions individually using Eq. 3. The DIj included Education (EDU), Socio-demographic (SODEM), Health (HEL), Employment and Economy (EMECO) and, Transport (TRANS).

$$
\begin{gathered}
\text { Index }_{\text {shi }}=\frac{S_{h-S_{\min }}}{S_{\max }-S_{\min }} \\
\text { Index }_{\text {shi }}=\frac{S_{h-S_{\min }}}{S_{\max -} S_{\min }}
\end{gathered}
$$

$S_{h}$ is the unstandardized value of $i^{\text {th }}$ row of k variable for block $b ; S_{\min }$ and $S_{\max }$ is the minimum and maximum value of $\mathrm{k}$ variable; Index shis the standardized value which applying in the further calculation.

$$
D I_{j}=\frac{\sum_{i=37}^{n} V 1_{i k j b}+V 2_{i k j b}+V 3_{i k j b}+\cdots V n_{i k j b}}{n}
$$

Here, $D I_{j}$ represents five dimensions mentioned in the above discussion; $V 1_{i k j b} \ldots V n_{i k j b}$ is the standardized value of $i^{\text {th }}$ row of $k$ variable of $j$ dimension of $b$ block.

In the final stage, the five dimensional disparity indices (DIj) aggregated with weighted by applying Eq. 4.

$$
M D I_{b}=\frac{W_{E D U} D I_{E D U}+W_{S O D E M} D I_{S O D E M}+W_{H E L} D I_{H E L}+W_{E M E C O} D I_{E M E C O}+W_{T R A N S} D I_{T R A N S}}{W_{E D U}+W_{S O D E M} W_{H E L}+W_{E M E C O}+W_{T R A N S}}
$$

Where the $M D I_{b}$ is the Multi-dimensional vulnerability index for the block $b$, and $W_{E D U} \ldots W_{\text {TRANS }}$ is the weightage of the five major dimensions. The weights are determined by the number of variables employed for each dimension calculation. It ensures that all variable equally represents to the overall index (Adu et al. 2013). Moreover, in analyzing the spatial pattern of regional disparity and development, assigning the weight of indicators 
deliversprecise and comparable results (Pal, 1995). The blocks having the highest index value are termed as highest disparity and least developed and vice versa.

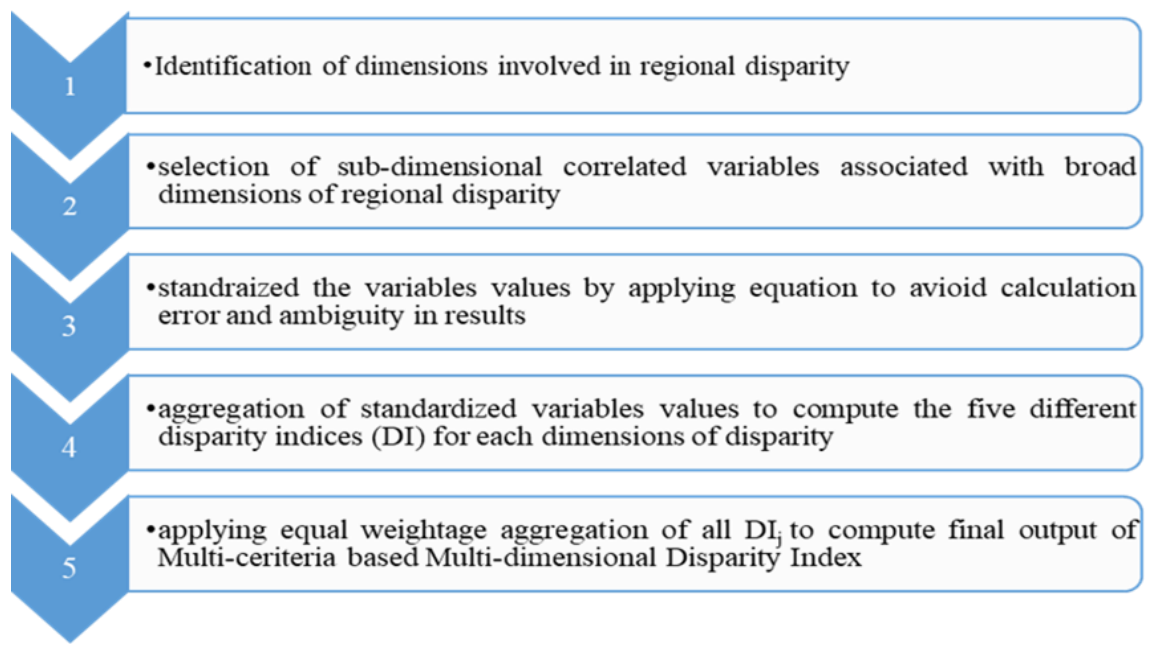

Figure 3. Sequential steps of proposed methodology

\subsection{Classification of Stages of Development}

Moreover, the study focused on depicting the inter-block stage of development in selected indicators using dimensional disparity values. For this purpose, placement of mean and standard deviation is a standardized classification process of different stages of development (Kumar \& Rani, 2019; Narain et al., 2007). It provides a meaningful classification that helps to compare inter-regional development. The criteria of categorization of the stage of development suggested by Kumar \& Rani (2019) ; Narain et al. (2007) as follows:

Stage I (Low Developed): Index value $\geq$ (Mean + Standard Deviation)

Stage II (Lower Middle Developed): Mean < Index value < (Mean + Standard Deviation)

Stage III (Higher Middle Developed): (Mean - Standard Deviation) < Index value < Mean

Stage IV (High Developed): Index Value $\leq$ (Mean - Standard Deviation)

\section{Results and Discussion}

The part of results and discussions elaborately addresses regional disparity issues in approaching the multi-dimensional aspects of regional development and its inter-block spatial variability. The mapping of regional disparity helps identify the backward blocks, which concise the task of policymakers in preparing a best-fit development plan. It provides a comprehensive outline of the spatial variability of health, education, economy, socio- 
demography, and transport infrastructure. Also, it provides an overview of the socioeconomic development of selected parts of JAD.

\subsection{Health Aspect}

Equivalent health infrastructure and healthcare accessibility is the crucial element for the regional development. Healthcare accessibility defines access to health centers and provides better service outcomes (Lakshmi \& Sahoo, 2013). Human wellbeing depends on institutional health infrastructure, the availability of doctors and health workers, governance, and logistic support (Banu \& Biswas, 2021). In their study, Banu \& Biswas (2021) examined that regional disparity largely prevailed in west Bengal, specifically in Border adjacent areas that abridged inhabitants' wellbeing opportunity. Many authors reveal the situational importance of health indicators and the importance of healthcare accessibility (Akthar \& Izhar, 1986; Banu \& Biswas, 2021; Rekha, 2017). Akthar \& Izhar (1986) studied the spatial variation of health infrastructure across India and compared it with Zambia. The regional disparity existed in India regarding health centers and sub-centers distribution, expenditure on health, hospital, and bed facilities, and the pattern of health care facilities (Akthar \& Izhar, 1986), which hamper the process of regional growth and improvement of human resource. The disparity existed both in rural and urban areas. However, rural areas are more likely to expouse in front of deprivation incidence than urban areas (Akthar\& Izhar, 1986). Health has critically delineated socio-economic stability and human development (Miao \& Wu, 2016). Accessibility of health facilities also spatially varied, which hampered the regional development goal.

Table 3. Health Disparity Index measured for each blocks of Jalpaiguri Administrative Division, West Bengal (Census of India, 2011a, b, c)

\begin{tabular}{lcccccc}
\hline \multirow{2}{*}{ Blocks } & HP & BD & DT & FWC & CM5 & $\begin{array}{c}\text { Health } \\
\text { Disparity } \\
\text { Index } \\
\text { (DI }\end{array}$ \\
\cline { 2 - 6 } & & & & & & 0.040 \\
\hline Alipurduar-I & 1.000 & 1.000 & 1.000 & 0.040 & 0.854 & 0.209 \\
Alipurduar-II & 0.803 & 0.347 & 0.302 & 0.040 & 0.808 & 0.271 \\
Coochbehar-I & 0.744 & 0.319 & 0.206 & 0.068 & 0.031 & 0.048 \\
Coochbehar-II & 0.631 & 0.307 & 0.199 & 0.062 & 0.031 & 0.140 \\
Darjeeling-Pulbazar & 0.587 & 0.282 & 0.197 & 0.388 & 0.963 & 0.312 \\
Dhupguri & 0.556 & 0.265 & 0.186 & 0.000 & 0.755 & 0.307 \\
Dinhata-I & 0.501 & 0.256 & 0.143 & 0.020 & 0.820 & 0.170 \\
Dinhata-II & 0.478 & 0.226 & 0.142 & 0.031 & 0.820 & 0.220 \\
Falakata & 0.447 & 0.219 & 0.123 & 0.019 & 0.734 & 0.205 \\
Gorubathan & 0.411 & 0.217 & 0.122 & 0.861 & 0.997 & 0.571 \\
Haldibari & 0.374 & 0.200 & 0.110 & 0.132 & 0.842 & 0.261 \\
Continued & & & & & & \\
\hline
\end{tabular}




\begin{tabular}{lcccccc}
\hline \multicolumn{1}{c}{ Blocks } & \multicolumn{3}{c}{ Standardized Values for indexing } & Health \\
\cline { 2 - 6 } & HP & BD & DT & FWC & CM5 & $\begin{array}{c}\text { Disparity } \\
\text { Index } \\
\text { (DI IEL) }\end{array}$ \\
\hline Jalpaiguri & 0.356 & 0.199 & 0.107 & 0.012 & 0.607 & 0.226 \\
Kalchini & 0.338 & 0.196 & 0.099 & 0.017 & 0.885 & 0.289 \\
Kalimpong-I & 0.315 & 0.168 & 0.090 & 0.691 & 0.988 & 0.526 \\
Kalimpong-II & 0.302 & 0.162 & 0.090 & 0.778 & 0.978 & 0.505 \\
Kharibari & 0.293 & 0.139 & 0.089 & 0.123 & 0.978 & 0.367 \\
Kumargram & 0.276 & 0.119 & 0.087 & 0.048 & 0.851 & 0.260 \\
Kurseong & 0.259 & 0.104 & 0.085 & 0.538 & 0.994 & 0.456 \\
Madarihat-Birpara & 0.255 & 0.099 & 0.080 & 0.046 & 0.560 & 0.325 \\
Mal & 0.250 & 0.098 & 0.074 & 0.017 & 0.715 & 0.308 \\
Mathabhanga-I & 0.232 & 0.093 & 0.065 & 0.040 & 0.932 & 0.203 \\
Mathabhanga-II & 0.228 & 0.091 & 0.062 & 0.036 & 0.929 & 0.238 \\
Matigara & 0.180 & 0.083 & 0.062 & 0.141 & 0.000 & 0.475 \\
Maynaguri & 0.170 & 0.058 & 0.057 & 0.012 & 0.650 & 0.204 \\
Mekhliganj & 0.159 & 0.058 & 0.055 & 0.074 & 1.000 & 0.265 \\
Metiali & 0.156 & 0.058 & 0.055 & 0.112 & 0.836 & 0.374 \\
Mirik & 0.134 & 0.055 & 0.042 & 0.351 & 1.000 & 0.564 \\
Nagrakata & 0.129 & 0.054 & 0.042 & 0.100 & 0.746 & 0.440 \\
Naxalbari & 0.116 & 0.049 & 0.035 & 0.288 & 0.963 & 0.368 \\
Phansidewa & 0.115 & 0.045 & 0.029 & 0.224 & 0.981 & 0.310 \\
Rajganj & 0.115 & 0.045 & 0.026 & 0.005 & 0.582 & 0.163 \\
RangliRangliot & 0.114 & 0.042 & 0.021 & 1.000 & 0.991 & 0.580 \\
Sitai & 0.111 & 0.042 & 0.015 & 0.122 & 1.000 & 0.307 \\
Sitalkuchi & 0.086 & 0.030 & 0.011 & 0.055 & 1.000 & 0.252 \\
Sukhiapokhri-Jorebunglow & 0.066 & 0.020 & 0.011 & 0.601 & 0.997 & 0.424 \\
Tufanganj-I & 0.027 & 0.007 & 0.010 & 0.030 & 1.000 & 0.247 \\
Tufanganj-II & 0.000 & 0.000 & 0.000 & 0.054 & 1.000 & 0.246 \\
\hline & & & & & &
\end{tabular}

In the present study, the author attempts to measure the regional disparity in health aspects, including hospitals, availability of doctors, beds availability, family welfare centers, and mortality rate (under five years of age). The index score was categorized into five levels (very low to very high) to examine the regional disparity better. The health index score ranges from 0.048 to 0.580 (Table 3). Table 3 indicates that the block Rangli-rangit has ranked last (0.580)), and the block Coochbehar-I (0.048) has been ranked first in the health disparity index. It has been further observed that the relative variation in health facilities has much higher among the 37 Community Development Blocks of the five districts under the Jalpaiguri Administrative Division (Figure. 4). Figure 4 indicates that only two blocks, Coochbehar-I and Coochbehar-II, have a very low disparity in selected health variables. 


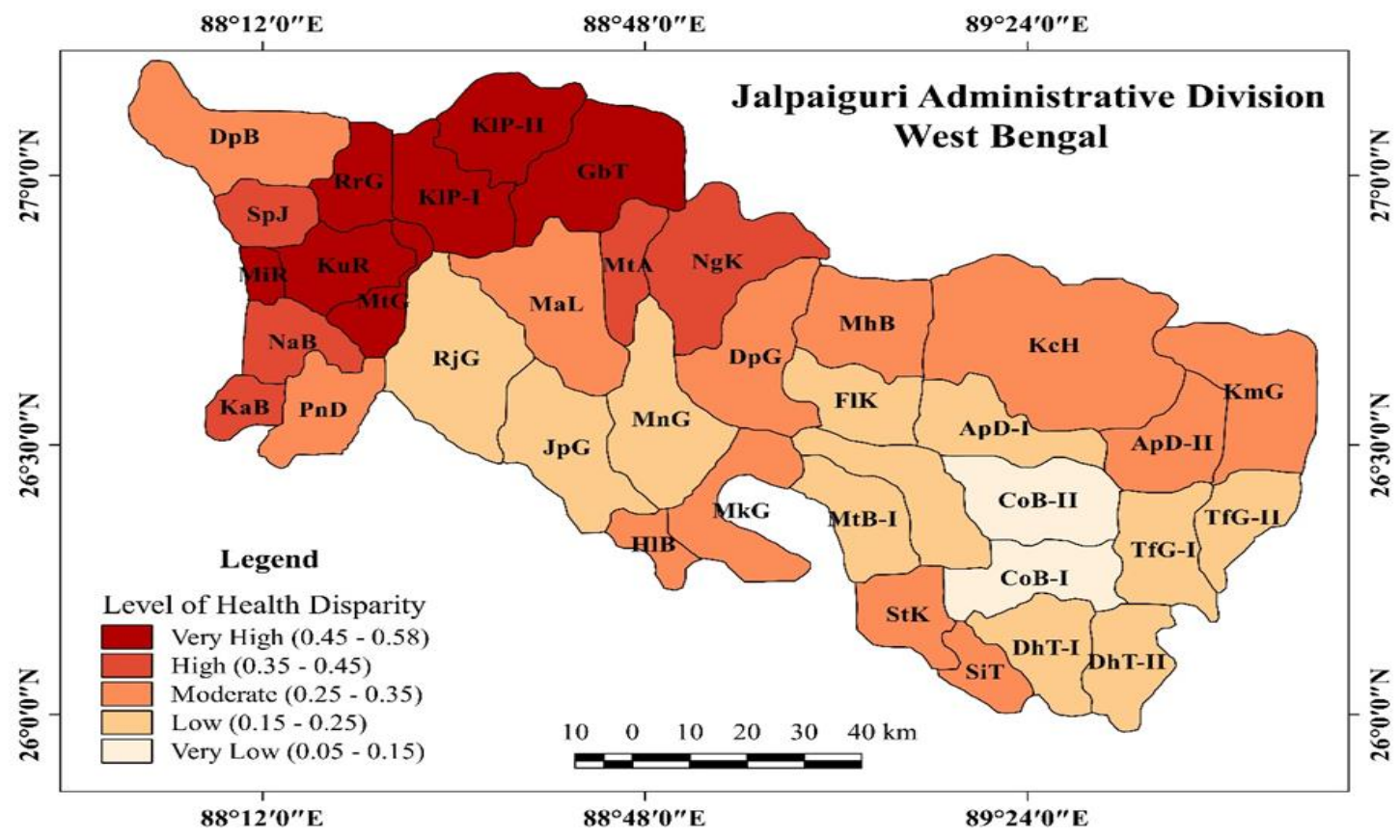

Figure 4. Inter-block spatial pattern of Health Disparity Index

In contrast, Mirik, Kurseong, Matigara, Rangli-rangit, Kalimpong-I, Kalimpong-II, and Gorubathan (four blocks from Darjeeling district and three blocks from Kalimpong district) has very high disparity, covered about 15.48 percent of the area and 8.27 percent of the population (Table 9). The study revealed that most of the blocks from Jalpaiguri and Alipurduar district moderately developed in health infrastructure. The result highlights an imbalanced pattern of development of necessary health infrastructure across the selected study area. For example, the hilly part (Darjeeling district and Kalimpong district) has a very high disparity in the availability of government hospitals, beds, and availability of doctors; whereas, the plain land of Coochbehar, part of Alipurduar, and part of Jalpaiguri district score low to the moderate disparity in health facility development. The primary reason behind this is an unequal and inadequate distribution of hospitals, doctors, primary health care facilities, and necessary logistic support. The cause to maximize the health expenditure of the population, and also they suffer from less accessibility of good health facilities.

It is evident of the developmental profile from the information presented in Table 8. Seven blocks is low developed, six blocks are low middle developed, twenty blocks is high middle developed, and four blocks is highly developed in terms of health infrastructure as depicted in Table 8. It implies that only a few blocks like Coochbehar-I, Coochbehar-II, 
Dinhata-I, and Rajganj achieved the desired development in the health aspect. However, 35.13 percent of blocks experienced low and low middle development, where the majority of blocks belong to Darjeeling and Kalimpong district. It is a concerning issue for both districts, also hamper the future policy implication. Generally, the lack of hospitals, beds, and doctors in the proportion of the population is alarming for these blocks.

\subsection{Educational Aspect}

Education is a fundamental component of human development (Das, 2018). It also helps a region for the transformation process from underdeveloped to developing. So, the regional disparity in the educational aspect directly influences the variability of regional development at the macro-level. Brandt (1980) stated that educational development is a crucial factor that helps achieve the overall development goal and enhance the capability to transform human resources into human capital.

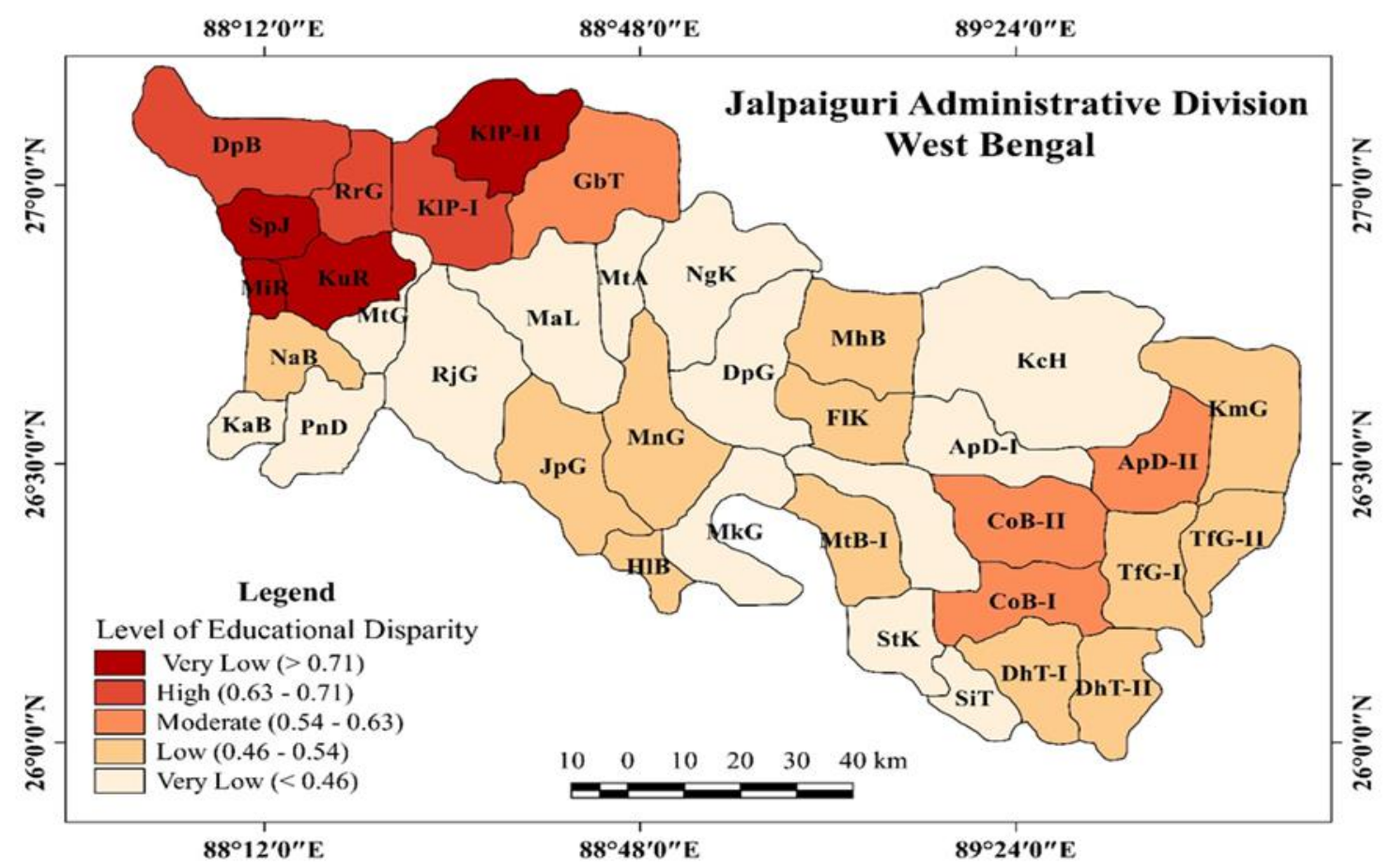

Figure 5. Inter-block spatial pattern of Educational Disparity Index 
Human capital is an essential asset under the assets pentagon of sustainable livelihood (ALC India, 2018). It helps improve the capacity and skills of people, able to diversify the occupational opportunities which reduced the chance of exposure from livelihood vulnerability. Here, vulnerability means joblessness, poverty, a low wage. Education also a significant part of human development (Das, 2018). Therefore, educational infrastructure needs to be equally distributed for inclusive regional development and implementation of smooth governance. The regional gap in the access and opportunities of educational facilities, evident to less developed region as well (Biriescu \& Babaita, 2014). The Special school (preprimary, Anganwari) and primary school are the base of educational development in India. Unequal distribution of school reduces the chance of enrollment of the student. Further, the distance of the school from the house also hampers the growth of a region's human resource, even forcing students to drop their education at an early stage, especially the scenario is worst for female students (Biswas, 2016; Rao \& Gupta, 2006).

The persistence inequality of educational facilities across the region coupled with inter-block disparity in education index. The education index ranges from 0.373 to 0.799 (Table 4). Out of thirty-seven blocks, only four blocks, Sukhiapokhri-jorebuglow, Mirik, Kurseong, and Kalimpong-II, have a high education facility disparity (Figure. 5). Total six blocks included under high (Darjeeling-phulbazar, Rangli-rangit, and Kalimpong-I) and moderate (Alipurduar-II, Coochbehar-I, and Coochbehar-I) disparity in educational aspects. The surprising fact is that among nine blocks of Darjeeling district, six blocks are very high to moderate disparity (Figure. 5). Table 9 reveals that in the educational sector, fourteen blocks are found to be very low disparity, covered area of about 40.08 percent and population of 41.17 percent. Twelve blocks with an area of 32.06 percent and a population of 37.92 percent are the low disparity category. The results indicate that spatial variation in the disparity of educational aspects has existed in the study area. Although, the disparity is high in the part of the mountainous blocks due to the physiographic inaccessibility and hindrances. The educational development is also variably experienced by the selected blocks. The blocks of Darjeeling-Pulbazar, Kalimpong-I, Kalimpong-II, Kurseong, Mirik, Rangli-rangit, and Sukhiapokhri-Jorebunglow experienced low development in the educational dimension (Table 8). 
Table 4. Educational Disparity Index measured for each blocks of Jalpaiguri Administrative Division, West Bengal (Census of India, 2011a, b, c)

\begin{tabular}{|c|c|c|c|c|c|c|c|c|c|c|c|c|c|c|}
\hline \multirow[b]{2}{*}{ Blocks } & \multicolumn{13}{|c|}{ Standardized Values for indexing } & \multirow{2}{*}{$\begin{array}{c}\text { Educational } \\
\text { Disparity } \\
\text { Index } \\
\text { (DI EDU) }\end{array}$} \\
\hline & PS & MS & $\mathrm{SS}$ & HS & SNS & PTR $_{P S}$ & $\mathrm{PTR}_{\mathrm{MS}}$ & PTRSS & $\mathrm{PTR}_{\mathrm{HS}}$ & $\mathrm{PTR}_{\text {SNS }}$ & $\mathrm{TL}$ & $\mathrm{FL}$ & TRFL & \\
\hline Alipurduar-I & 0.197 & 0.028 & 0.266 & 0.674 & 0.351 & 0.000 & 0.530 & 0.510 & 0.799 & 0.557 & 0.702 & 0.743 & 0.558 & 0.455 \\
\hline Alipurduar-II & 0.281 & 0.069 & 0.190 & 0.834 & 0.349 & 0.772 & 0.717 & 0.521 & 0.850 & 0.475 & 0.681 & 0.732 & 0.730 & 0.554 \\
\hline Coochbehar-I & 0.165 & 0.350 & 0.412 & 0.865 & 0.276 & 0.770 & 0.631 & 0.428 & 0.842 & 0.695 & 0.719 & 0.764 & 0.730 & 0.588 \\
\hline Coochbehar-II & 0.175 & 0.183 & 0.153 & 0.914 & 0.122 & 0.549 & 0.652 & 0.000 & 0.812 & 0.682 & 0.946 & 0.985 & 0.959 & 0.548 \\
\hline Darjeeling-Pulbazar & 0.852 & 0.268 & 0.275 & 0.043 & 0.742 & 0.550 & 0.939 & 0.801 & 0.984 & 0.766 & 0.918 & 0.905 & 0.933 & 0.691 \\
\hline Dhupguri & 0.065 & 0.010 & 0.148 & 0.716 & 0.394 & 0.814 & 0.559 & 0.633 & 0.845 & 0.333 & 0.390 & 0.388 & 0.384 & 0.437 \\
\hline Dinhata-I & 0.180 & 0.215 & 0.121 & 0.389 & 0.224 & 0.614 & 0.658 & 0.148 & 0.652 & 1.000 & 0.562 & 0.633 & 0.645 & 0.465 \\
\hline Dinhata-II & 0.241 & 0.187 & 0.258 & 0.424 & 0.223 & 0.765 & 0.437 & 0.183 & 0.687 & 0.998 & 0.520 & 0.584 & 0.602 & 0.470 \\
\hline Falakata & 0.128 & 0.038 & 0.035 & 0.752 & 0.295 & 0.830 & 0.715 & 0.425 & 0.904 & 0.418 & 0.535 & 0.583 & 0.492 & 0.473 \\
\hline Gorubathan & 0.934 & 0.245 & 0.425 & 0.354 & 0.562 & 0.712 & 0.684 & 0.576 & 0.637 & 0.610 & 0.734 & 0.713 & 0.735 & 0.609 \\
\hline Haldibari & 0.326 & 1.000 & 0.051 & 0.974 & 0.356 & 0.704 & 0.290 & 0.372 & 0.813 & 0.414 & 0.374 & 0.437 & 0.451 & 0.505 \\
\hline Jalpaiguri & 0.266 & 0.000 & 0.293 & 0.875 & 0.255 & 0.493 & 0.515 & 0.682 & 0.861 & 0.379 & 0.590 & 0.610 & 0.558 & 0.490 \\
\hline Kalchini & 0.000 & 0.081 & 0.192 & 0.424 & 0.680 & 0.751 & 0.880 & 0.657 & 0.810 & 0.598 & 0.362 & 0.323 & 0.180 & 0.457 \\
\hline Kalimpong-I & 0.815 & 0.311 & 0.432 & 0.000 & 0.630 & 0.672 & 0.954 & 0.724 & 0.698 & 0.859 & 0.948 & 1.000 & 1.000 & 0.696 \\
\hline Kalimpong-II & 0.735 & 0.354 & 0.735 & 0.569 & 0.765 & 0.849 & 0.912 & 0.653 & 1.000 & 0.538 & 0.866 & 0.883 & 0.911 & 0.752 \\
\hline Kharibari & 0.398 & 0.153 & 0.263 & 0.750 & 0.447 & 0.698 & 0.081 & 0.777 & 0.000 & 0.807 & 0.287 & 0.265 & 0.192 & 0.394 \\
\hline Kumargram & 0.193 & 0.241 & 0.057 & 0.754 & 0.742 & 0.642 & 0.849 & 0.408 & 0.817 & 0.601 & 0.524 & 0.568 & 0.451 & 0.527 \\
\hline Kurseong & 1.000 & 0.089 & 1.000 & 0.524 & 0.826 & 0.755 & 0.785 & 0.841 & 0.912 & 0.655 & 0.935 & 0.900 & 0.847 & 0.775 \\
\hline Madarihat-Birpara & 0.079 & 0.011 & 0.214 & 0.742 & 0.831 & 1.000 & 0.624 & 0.596 & 0.784 & 0.661 & 0.306 & 0.314 & 0.277 & 0.495 \\
\hline Mal & 0.109 & 0.157 & 0.137 & 0.301 & 0.679 & 0.595 & 0.533 & 0.533 & 0.774 & 0.548 & 0.237 & 0.257 & 0.219 & 0.391 \\
\hline Mathabhanga-I & 0.201 & 0.783 & 0.007 & 1.000 & 0.285 & 0.655 & 0.342 & 0.403 & 0.556 & 0.419 & 0.482 & 0.485 & 0.500 & 0.471 \\
\hline Mathabhanga-II & 0.217 & 0.245 & 0.038 & 0.791 & 0.178 & 0.460 & 0.187 & 0.651 & 0.375 & 0.527 & 0.537 & 0.561 & 0.578 & 0.411 \\
\hline Matigara & 0.173 & 0.059 & 0.181 & 0.399 & 0.307 & 0.598 & 0.031 & 1.000 & 0.691 & 0.413 & 0.635 & 0.639 & 0.500 & 0.433 \\
\hline Maynaguri & 0.190 & 0.069 & 0.213 & 0.637 & 0.178 & 0.700 & 0.963 & 0.578 & 0.772 & 0.388 & 0.675 & 0.696 & 0.636 & 0.515 \\
\hline Mekhliganj & 0.261 & 0.769 & 0.000 & 0.922 & 0.000 & 0.757 & 0.000 & 0.337 & 0.667 & 0.657 & 0.379 & 0.391 & 0.386 & 0.425 \\
\hline $\begin{array}{l}\text { Metiali } \\
\text { Continued }\end{array}$ & 0.157 & 0.177 & 0.169 & 0.219 & 0.565 & 0.706 & 0.850 & 0.501 & 0.761 & 0.493 & 0.269 & 0.197 & 0.114 & 0.398 \\
\hline
\end{tabular}




\begin{tabular}{|c|c|c|c|c|c|c|c|c|c|c|c|c|c|c|}
\hline \multirow[b]{2}{*}{ Blocks } & \multicolumn{13}{|c|}{ Standardized Values for indexing } & \multirow{2}{*}{$\begin{array}{l}\text { Educational } \\
\text { Disparity } \\
\text { Index } \\
\text { (DIEDU) }\end{array}$} \\
\hline & PS & MS & SS & $\mathrm{HS}$ & SNS & $\mathrm{PTR}_{\mathrm{PS}}$ & $\mathrm{PTR}_{\mathrm{MS}}$ & PTRSS & $\mathrm{PTR}_{\mathrm{HS}}$ & $\mathrm{PTR}_{\mathrm{SNS}}$ & $\mathrm{TL}$ & FL & TRFL & \\
\hline Mirik & 0.959 & 0.240 & 0.933 & 0.537 & 1.000 & 0.727 & 0.940 & 0.894 & 0.934 & 0.519 & 0.920 & 0.876 & 0.903 & 0.799 \\
\hline Nagrakata & 0.050 & 0.051 & 0.023 & 0.609 & 0.867 & 0.782 & 1.000 & 0.173 & 0.914 & 0.573 & 0.000 & 0.000 & 0.000 & 0.388 \\
\hline Naxalbari & 0.276 & 0.137 & 0.187 & 0.740 & 0.395 & 0.434 & 0.238 & 0.829 & 0.812 & 0.733 & 0.668 & 0.655 & 0.364 & 0.498 \\
\hline Phansidewa & 0.275 & 0.055 & 0.132 & 0.818 & 0.684 & 0.804 & 0.272 & 0.877 & 0.794 & 0.488 & 0.150 & 0.170 & 0.176 & 0.438 \\
\hline Rajganj & 0.047 & 0.017 & 0.154 & 0.338 & 0.089 & 0.681 & 0.965 & 0.562 & 0.827 & 0.000 & 0.508 & 0.546 & 0.573 & 0.408 \\
\hline Rangli-rangliot & 0.907 & 0.400 & 0.354 & 0.531 & 0.582 & 0.629 & 0.872 & 0.376 & 0.870 & 0.773 & 0.904 & 0.883 & 0.911 & 0.692 \\
\hline Sitai & 0.186 & 0.234 & 0.187 & 0.413 & 0.441 & 0.889 & 0.289 & 0.241 & 0.668 & 0.878 & 0.071 & 0.176 & 0.182 & 0.373 \\
\hline Sitalkuchi & 0.221 & 0.561 & 0.156 & 0.635 & 0.226 & 0.298 & 0.820 & 0.484 & 0.563 & 0.554 & 0.427 & 0.473 & 0.488 & 0.454 \\
\hline $\begin{array}{l}\text { Sukhiapokhri- } \\
\text { Jorebunglow }\end{array}$ & 0.766 & 0.266 & 0.391 & 0.554 & 0.912 & 0.880 & 0.899 & 0.786 & 0.952 & 0.844 & 1.000 & 0.961 & 0.966 & 0.783 \\
\hline Tufanganj-I & 0.178 & 0.441 & 0.187 & 0.775 & 0.357 & 0.664 & 0.295 & 0.285 & 0.744 & 0.812 & 0.584 & 0.628 & 0.645 & 0.507 \\
\hline Tufanganj-II & 0.288 & 0.728 & 0.154 & 0.726 & 0.329 & 0.701 & 0.211 & 0.090 & 0.741 & 0.748 & 0.681 & 0.701 & 0.713 & 0.524 \\
\hline
\end{tabular}

\subsection{Employment and Economic Aspect}

The regional (inter-block) disparities in the employment and economic aspect are examined based on eight indicators (Table 2 and 5). Figure 6 indicates a substantial regional variation of employment and economic aspect in Jalpaiguri AD. Among 37 blocks, six blocks have a very high disparity in EMECO. Three blocks of Coochbehar district (Mathabhanga-I, Coochbehar-I, and Tufanganj-I), one from Darjeeling (Matigara), Kalimpong (Gorubathan), and Jalpaiguri district (Mal) fall under the very high disparity category. The very high disparity in employment and economic aspect (EMECO) covered about 14.18 percent area and a population of 15.84 percent (Table 9). Seven blocks have an area of 21.48 percent, and 17.39 percent of the population belongs to the high disparity category. In contrast, only four blocks (10.18 percent area and 13.12 percent population) fall under the very low disparity group (Table 9). The results indicate that majority of blocks score high, moderate, and low disparity in EMECO. The moderate and low economic development of the blocks of Darjeeling, Jalpaiguri, and part of Alipurduar and Coochbehar districts is lack of manufacturing industry and more dependence on tea industry and agriculture. 
As per Table 8, seventeen districts were found to be low and low middle developed in the EMECO dimension.Coochbehar-I, Gorubathan, Madarihat-Birpara, Mathabhanga-I, Matigara, Metiali, and Tufanganj-I blocks are included in the stage I of economic development. Also, Darjeeling-Pulbazar, Jalpaiguri, Kalchini, Kalimpong-II, Kurseong, Mekhliganj, Naxalbari, RangliRangliot, Sitai, Tufanganj-II blocks are in state II of development (Table 8). This means that majority of the blocks are facing an alarming situation in terms of the development of eight indicators selected in the EMECO dimension.

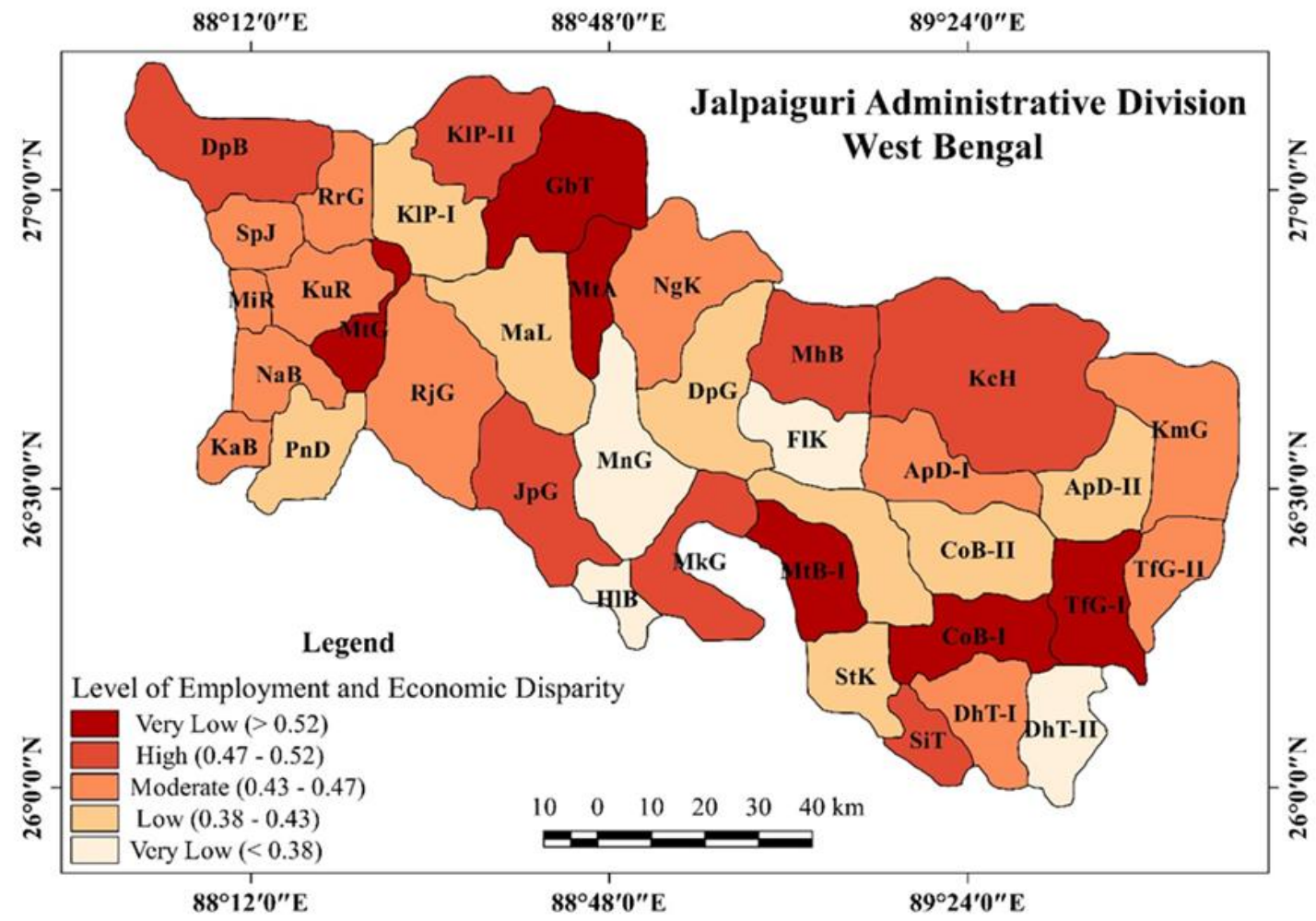

Figure 6. Inter-block spatial pattern of Employment and Economic Disparity Index 
Table 5. Employment and Economic Disparity Index measured for each blocks of Jalpaiguri Administrative Division, West Bengal (Census of India, 2011a, b, c)

\begin{tabular}{|c|c|c|c|c|c|c|c|c|c|}
\hline \multirow{2}{*}{ Blocks } & \multicolumn{8}{|c|}{ Standardized Values } & \multirow{2}{*}{$\begin{array}{l}\text { Employment } \\
\text { and Economic } \\
\text { Disparity } \\
\text { Index } \\
\text { (DIEMECo) }\end{array}$} \\
\hline & $\mathrm{CL}$ & $\overline{\mathrm{AL}}$ & HW & $\mathrm{OW}$ & WPR & $\mathrm{MW}$ & MARW & BAN & \\
\hline Alipurduar-I & 0.300 & 0.335 & 0.008 & 0.417 & 0.585 & 0.772 & 0.488 & 0.533 & 0.430 \\
\hline Alipurduar-II & 0.358 & 0.269 & 0.229 & 0.315 & 0.438 & 0.548 & 0.581 & 0.600 & 0.417 \\
\hline Coochbehar-I & 0.469 & 0.375 & 0.494 & 0.278 & 0.592 & 0.759 & 0.508 & 1.000 & 0.559 \\
\hline Coochbehar-II & 0.349 & 0.347 & 0.224 & 0.369 & 0.236 & 0.749 & 0.183 & 0.647 & 0.388 \\
\hline Darjeeling-Pulbazar & 0.556 & 0.791 & 0.288 & 0.494 & 0.595 & 0.344 & 0.941 & 0.000 & 0.501 \\
\hline Dhupguri & 0.267 & 0.359 & 0.042 & 0.449 & 0.533 & 0.609 & 0.608 & 0.371 & 0.405 \\
\hline Dinhata-I & 0.518 & 0.241 & 0.293 & 0.186 & 0.457 & 0.792 & 0.347 & 0.715 & 0.443 \\
\hline Dinhata-II & 0.574 & 0.000 & 0.033 & 0.032 & 0.453 & 0.899 & 0.233 & 0.643 & 0.358 \\
\hline Falakata & 0.337 & 0.247 & 0.070 & 0.333 & 0.368 & 0.738 & 0.319 & 0.584 & 0.374 \\
\hline Gorubathan & 0.527 & 0.635 & 0.342 & 0.412 & 0.462 & 0.165 & 1.000 & 0.647 & 0.524 \\
\hline Haldibari & 0.656 & 0.142 & 0.030 & 0.064 & 0.291 & 0.803 & 0.179 & 0.858 & 0.378 \\
\hline Jalpaiguri & 0.332 & 0.340 & 0.000 & 0.400 & 0.682 & 0.782 & 0.568 & 0.888 & 0.499 \\
\hline Kalchini & 0.069 & 0.884 & 0.094 & 0.890 & 0.508 & 0.682 & 0.507 & 0.445 & 0.510 \\
\hline Kalimpong-I & 0.398 & 0.353 & 0.038 & 0.360 & 0.439 & 0.154 & 0.990 & 0.509 & 0.405 \\
\hline Kalimpong-II & 0.741 & 0.637 & 0.002 & 0.310 & 0.276 & 0.000 & 0.996 & 0.848 & 0.476 \\
\hline Kharibari & 0.256 & 0.512 & 0.301 & 0.521 & 0.408 & 0.569 & 0.531 & 0.439 & 0.442 \\
\hline Kumargram & 0.239 & 0.499 & 0.295 & 0.524 & 0.447 & 0.437 & 0.704 & 0.404 & 0.444 \\
\hline Kurseong & 0.153 & 0.926 & 0.184 & 0.851 & 0.130 & 0.405 & 0.440 & 0.548 & 0.455 \\
\hline Madarihat-Birpara & 0.117 & 0.787 & 0.077 & 0.802 & 0.520 & 0.544 & 0.662 & 0.582 & 0.511 \\
\hline Mal & 0.178 & 0.606 & 0.074 & 0.653 & 0.293 & 0.508 & 0.487 & 0.508 & 0.413 \\
\hline Mathabhanga-I & 0.827 & 0.399 & 0.075 & 0.102 & 0.933 & 0.905 & 0.676 & 0.600 & 0.565 \\
\hline Mathabhanga-II & 0.587 & 0.241 & 0.179 & 0.153 & 0.460 & 0.795 & 0.346 & 0.634 & 0.424 \\
\hline Matigara & 0.000 & 1.000 & 0.146 & 1.000 & 0.317 & 1.000 & 0.000 & 0.795 & 0.532 \\
\hline Maynaguri & 0.507 & 0.320 & 0.076 & 0.265 & 0.167 & 0.607 & 0.266 & 0.498 & 0.338 \\
\hline Mekhliganj & 0.845 & 0.342 & 0.074 & 0.056 & 0.584 & 0.802 & 0.455 & 0.671 & 0.479 \\
\hline Metiali & 0.043 & 0.810 & 0.044 & 0.868 & 0.729 & 0.740 & 0.655 & 0.379 & 0.533 \\
\hline Mirik & 0.208 & 0.735 & 0.107 & 0.707 & 0.245 & 0.377 & 0.578 & 0.560 & 0.440 \\
\hline Nagrakata & 0.112 & 0.745 & 0.072 & 0.781 & 0.309 & 0.437 & 0.575 & 0.493 & 0.440 \\
\hline Naxalbari & 0.071 & 0.881 & 0.136 & 0.883 & 0.186 & 0.689 & 0.199 & 0.633 & 0.460 \\
\hline Phansidewa & 0.167 & 0.688 & 0.114 & 0.706 & 0.247 & 0.602 & 0.346 & 0.490 & 0.420 \\
\hline Rajganj & 0.150 & 0.723 & 0.255 & 0.723 & 0.254 & 0.675 & 0.277 & 0.509 & 0.446 \\
\hline RangliRangliot & 0.108 & 0.722 & 0.084 & 0.769 & 0.257 & 0.230 & 0.741 & 0.726 & 0.454 \\
\hline Sitai & 0.730 & 0.123 & 0.071 & 0.000 & 1.000 & 0.954 & 0.688 & 0.431 & 0.500 \\
\hline Sitalkuchi & 1.000 & 0.424 & 0.103 & 0.001 & 0.439 & 0.798 & 0.324 & 0.153 & 0.405 \\
\hline $\begin{array}{l}\text { Sukhiapokhri- } \\
\text { Jorebunglow }\end{array}$ & 0.093 & 0.915 & 0.139 & 0.889 & 0.000 & 0.537 & 0.182 & 0.685 & 0.430 \\
\hline Tufanganj-I & 0.411 & 0.324 & 1.000 & 0.230 & 0.526 & 0.778 & 0.427 & 0.679 & 0.547 \\
\hline Tufanganj-II & 0.485 & 0.346 & 0.531 & 0.246 & 0.460 & 0.637 & 0.509 & 0.458 & 0.459 \\
\hline
\end{tabular}

\subsection{Socio-demographic Aspect}

The socio-demographic aspect is a combination of social wealth and demographic characteristics. The social wealth included electricity, drinking water, and the proportion of subsidized food availability. The social and demographic phenomenon act as a vital edge for regional development and quality of life. For example, uncontrolled population growth creates enormous pressure on material and natural resources, affecting the other components 
of regional development. The social indicators variably represent the spatial pattern of development, because the development of social wealth positively improved the socioeconomic status of the population (Kumar \& Rani, 2019).

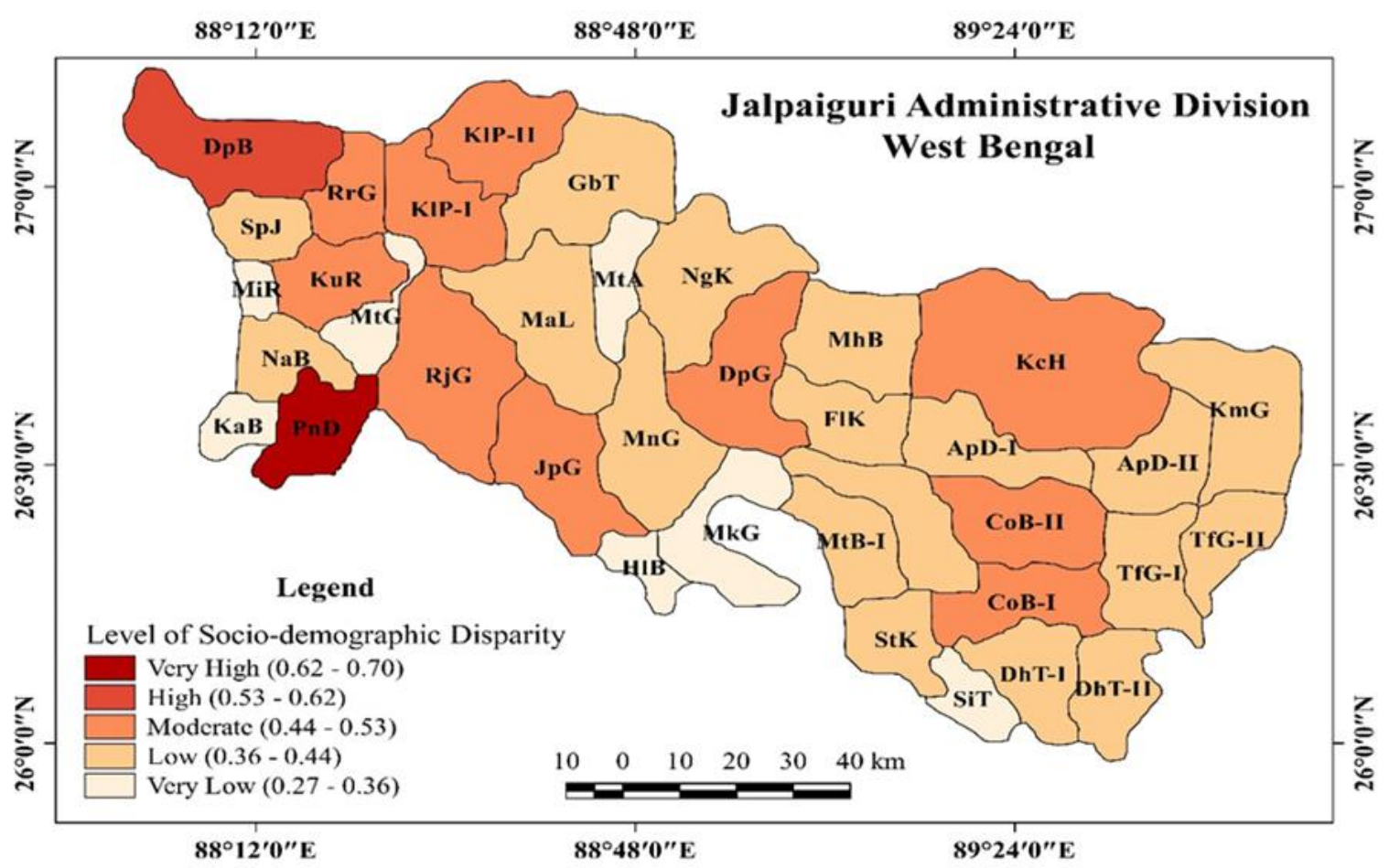

Figure 7. Inter-block spatial pattern of Socio-demographic Disparity Index

In the study, the socio-demographic disparity index was prepared based on five subcomponents (Table 2), including population, population density, electricity, drinking water facilities, and fair price shops. The calculated index value ranges from 0.373 to 0.799 (Table 6). The Mirik block has the highest disparity, and Sitai block has the lowest disparity in the socio-demographic disparity index. Tables 6 and 9 indicates most of the blocks have a low disparity in socio-demographic aspect, which covered an area of 48.90 percent and a population of 50.75 percent (Table 9 and Figure 7). Seven and ten blocks fall under the very low and moderate disparity category, respectively. Only the block Darjeeling-phulbazar is a high disparity covered 3.30 percent of the area and 1.72 percent of the population (Table 6 and 9). The Phansidewa block of Darjeeling district observed a very high disparity in the socio-demographic aspect, covered 2.48 percent of the area and 2.77 percent of the population. 
Table 6. Socio-demographic Disparity Index measured for each blocks of Jalpaiguri Administrative Division, West Bengal (Census of India, 2011a, b, c)

\begin{tabular}{|c|c|c|c|c|c|c|}
\hline \multirow[b]{2}{*}{ Blocks } & \multicolumn{5}{|c|}{ Standardized Values for indexing } & \multirow{2}{*}{$\begin{array}{c}\text { Socio- } \\
\text { demographic } \\
\text { Disparity } \\
\text { Index } \\
\text { (DI } \text { SODEM) }\end{array}$} \\
\hline & DEN & $\mathbf{T P}$ & $\mathbf{E L}$ & DW & FPS & \\
\hline Alipurduar-I & 0.649 & 0.319 & 0.376 & 0.508 & 0.197 & 0.410 \\
\hline Alipurduar-II & 0.560 & 0.323 & 0.376 & 0.525 & 0.208 & 0.398 \\
\hline Coochbehar-I & 0.383 & 0.936 & 0.376 & 0.550 & 0.097 & 0.468 \\
\hline Coochbehar-II & 0.393 & 1.000 & 0.376 & 0.550 & 0.117 & 0.487 \\
\hline Darjeeling-Pulbazar & 0.865 & 0.450 & 0.280 & 0.491 & 1.000 & 0.617 \\
\hline Dhupguri & 0.456 & 0.846 & 0.359 & 0.524 & 0.089 & 0.455 \\
\hline Dinhata-I & 0.286 & 0.789 & 0.369 & 0.535 & 0.116 & 0.419 \\
\hline Dinhata-II & 0.315 & 0.635 & 0.376 & 0.545 & 0.105 & 0.395 \\
\hline Falakata & 0.450 & 0.516 & 0.376 & 0.550 & 0.068 & 0.392 \\
\hline Gorubathan & 1.000 & 0.079 & 0.237 & 0.336 & 0.418 & 0.414 \\
\hline Haldibari & 0.562 & 0.122 & 0.362 & 0.507 & 0.005 & 0.311 \\
\hline Jalpaiguri & 0.591 & 0.603 & 0.376 & 0.550 & 0.101 & 0.444 \\
\hline Kalchini & 0.773 & 0.537 & 0.376 & 0.471 & 0.151 & 0.462 \\
\hline Kalimpong-I & 0.944 & 0.159 & 0.341 & 0.417 & 0.361 & 0.444 \\
\hline Kalimpong-II & 0.887 & 0.115 & 0.286 & 0.411 & 0.524 & 0.445 \\
\hline Kharibari & 0.504 & 0.352 & 0.086 & 0.372 & 0.102 & 0.283 \\
\hline Kumargram & 0.800 & 0.272 & 0.376 & 0.427 & 0.142 & 0.403 \\
\hline Kurseong & 0.907 & 0.268 & 0.129 & 0.464 & 0.474 & 0.448 \\
\hline Madarihat-Birpara & 0.679 & 0.280 & 0.376 & 0.455 & 0.121 & 0.382 \\
\hline Mal & 0.669 & 0.539 & 0.368 & 0.512 & 0.082 & 0.434 \\
\hline Mathabhanga-I & 0.561 & 0.540 & 0.367 & 0.544 & 0.123 & 0.427 \\
\hline Mathabhanga-II & 0.520 & 0.574 & 0.348 & 0.543 & 0.078 & 0.412 \\
\hline Matigara & 0.000 & 0.843 & 0.185 & 0.446 & 0.000 & 0.295 \\
\hline Maynaguri & 0.611 & 0.618 & 0.304 & 0.471 & 0.084 & 0.418 \\
\hline Mekhliganj & 0.697 & 0.310 & 0.184 & 0.427 & 0.076 & 0.339 \\
\hline Metiali & 0.648 & 0.055 & 0.348 & 0.529 & 0.041 & 0.324 \\
\hline Mirik & 0.797 & 0.000 & 0.000 & 0.000 & 0.553 & 0.270 \\
\hline Nagrakata & 0.852 & 0.080 & 0.350 & 0.450 & 0.126 & 0.372 \\
\hline Naxalbari & 0.378 & 0.666 & 0.340 & 0.569 & 0.038 & 0.398 \\
\hline Phansidewa & 0.583 & 0.883 & 1.000 & 1.000 & 0.056 & 0.704 \\
\hline Rajganj & 0.621 & 0.737 & 0.376 & 0.527 & 0.034 & 0.459 \\
\hline RangliRangliot & 0.903 & 0.133 & 0.285 & 0.550 & 0.364 & 0.447 \\
\hline Sitai & 0.558 & 0.144 & 0.359 & 0.550 & 0.083 & 0.339 \\
\hline Sitalkuchi & 0.542 & 0.419 & 0.351 & 0.531 & 0.065 & 0.382 \\
\hline Sukhiapokhri-Jorebunglow & 0.699 & 0.376 & 0.376 & 0.522 & 0.201 & 0.435 \\
\hline Tufanganj-I & 0.479 & 0.651 & 0.364 & 0.541 & 0.068 & 0.421 \\
\hline Tufanganj-II & 0.545 & 0.424 & 0.360 & 0.550 & 0.074 & 0.391 \\
\hline
\end{tabular}

\subsection{Transport Aspect}

Transport has to play a critical role in the developmental process within a region. It is obvious that disparities exist between inter-regional levels in terms of the betterment of 
transport and communication facilities. The dimension determines the level of transmission of goods and services (Das, 1999), accelerating the region's growth in a more sophisticated manner. In their studies, Li et al. (2020) found that regional development correlated with the diversifying transport network.

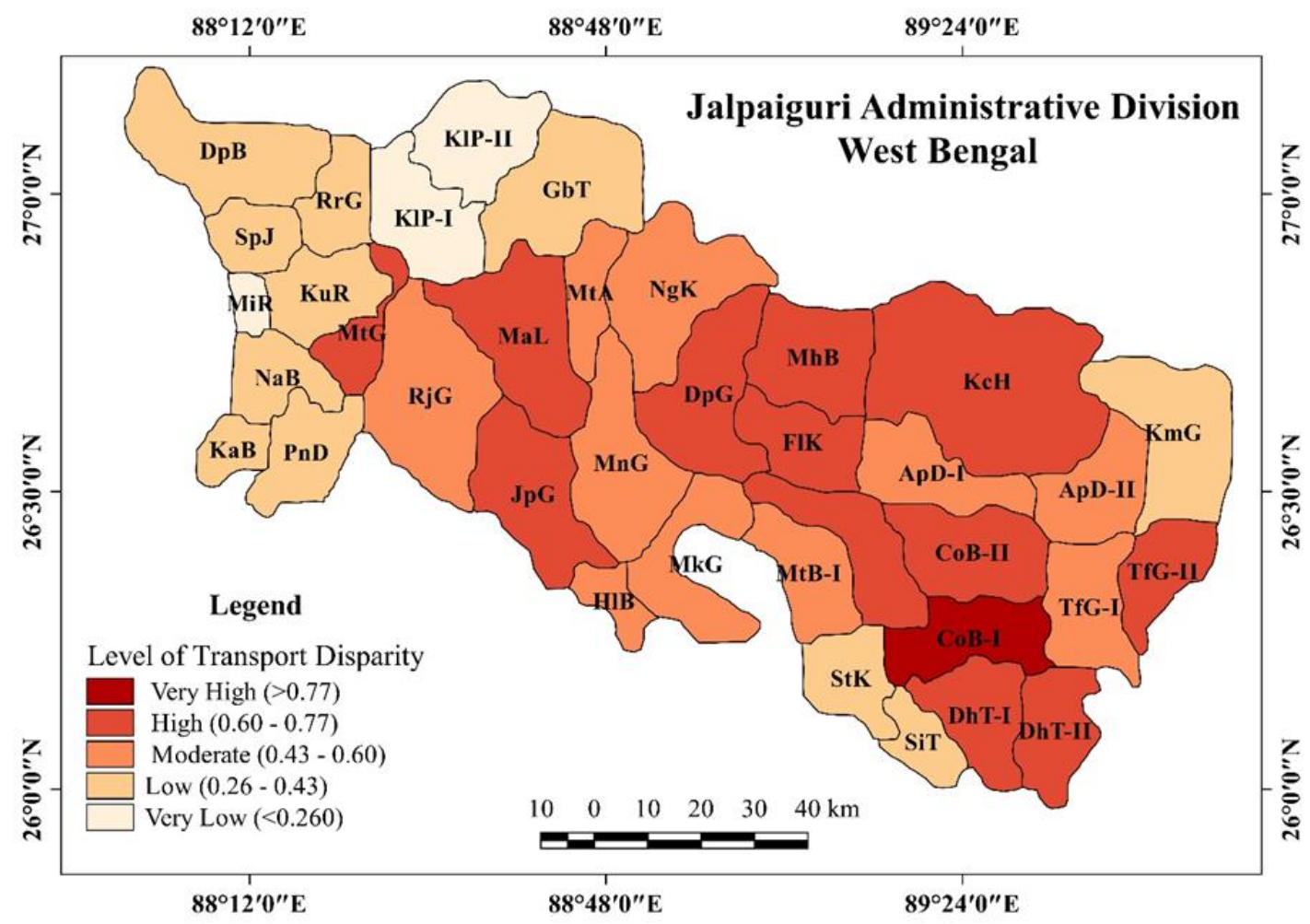

Figure 8. Inter-block spatial pattern of Transport Disparity Index

Here, three sub-dimensional variables have been considered to analyze the inter-block disparities and stages of development in the transport dimension (Table 2). These findings are demonstrated in Table 7 and Figure 8 . Table 7 shows that the highest disparity value of transport aspects, i.e., 0.947, is attained by Coochbehar-I, followed by the block Tufanganj-II (0.722), Coochbehar-II (0.718). In contrast, the lowest disparity value is attained by Kalimpong-II, i.e., 0.090. As seen in Figure 8, one block out of Thirty-seven blocks is found to be in the very high disparity category, and twelve blocks are found to be the high disparity category. The very high disparity category covers 2.86 percent of the area and 4.43 percent of the population (Table 9). The blocks under the high disparity group cover about 32.67 percent of the area and 39.30 percent of the population. Ten blocks covering about 28.32 percent of the area and 29.75 percent of the population are found to be a moderate disparity category. 
On the contrary, eleven and three blocks are found to be in the low and very low disparity categories. These blocks occupy about 26.22 percent, 5.72 percent of the area, and 19.52 percent, 2.55 percent of the population under the low and very low disparity category, respectively (Table 9). The mountainous part of the study area experienced intense development and an achievable level of disparity compared to other counterparts. This scenario is the one most likely to cause the importance of tourism and international border sharing. Darjeeling, Kalimpong, Kurseong, Mirk, and Dooars (Parts of Jalpaiguri and Alipurduar district) are the major tourist destination in West Bengal, share a significant proportion of revenue in the state economy. Further, Shiliguri is a significant business hub and significant transport node connecting entire India with northeast India. The following factors influence the equitable growth of the transport network across the district. However, only the development of transport networks does not provide an overall impact on the overall sustainable and inclusive regional development.

Table 7. Transport Disparity Index measured for each blocks of Jalpaiguri Administrative Division, West Bengal (Census of India, 2011a, b, c)

\begin{tabular}{|c|c|c|c|c|}
\hline \multirow[b]{2}{*}{ Blocks } & \multicolumn{3}{|c|}{ Standardized Values for indexing } & \multirow{2}{*}{$\begin{array}{c}\text { Transpor } \\
\text { Disparity } \\
\text { Index } \\
\text { (DI } \\
\text { (DRANS) }\end{array}$} \\
\hline & $\mathrm{RD}$ & $\mathrm{BR}$ & RS & \\
\hline Alipurduar-I & 0.381 & 0.781 & 0.200 & 0.454 \\
\hline Alipurduar-II & 0.340 & 0.813 & 0.200 & 0.451 \\
\hline Coochbehar-I & 0.902 & 0.938 & 1.000 & 0.947 \\
\hline Coochbehar-II & 0.569 & 0.984 & 0.600 & 0.718 \\
\hline Darjeeling-Pulbazar & 0.464 & 0.547 & 0.100 & 0.370 \\
\hline Dhupguri & 0.265 & 0.938 & 0.600 & 0.601 \\
\hline Dinhata-I & 0.390 & 0.984 & 0.700 & 0.691 \\
\hline Dinhata-II & 0.635 & 0.922 & 0.400 & 0.652 \\
\hline Falakata & 0.251 & 0.953 & 0.600 & 0.601 \\
\hline Gorubathan & 0.000 & 0.813 & 0.000 & 0.271 \\
\hline Haldibari & 0.253 & 1.000 & 0.400 & 0.551 \\
\hline Jalpaiguri & 0.217 & 0.969 & 0.700 & 0.629 \\
\hline Kalchini & 0.078 & 1.000 & 0.800 & 0.626 \\
\hline Kalimpong-I & 0.034 & 0.234 & 0.300 & 0.190 \\
\hline Kalimpong-II & 0.071 & 0.000 & 0.200 & 0.090 \\
\hline Kharibari & 0.139 & 0.922 & 0.100 & 0.387 \\
\hline Kumargram & 0.197 & 0.719 & 0.300 & 0.405 \\
\hline Kurseong & 0.005 & 0.969 & 0.200 & 0.391 \\
\hline Madarihat-Birpara & 0.223 & 0.984 & 0.600 & 0.602 \\
\hline Mal & 0.224 & 0.984 & 0.600 & 0.603 \\
\hline Mathabhanga-I & 0.274 & 0.656 & 0.800 & 0.577 \\
\hline Mathabhanga-II & 0.429 & 0.875 & 0.700 & 0.668 \\
\hline Continued & & & & \\
\hline
\end{tabular}




\begin{tabular}{|c|c|c|c|c|}
\hline \multirow[b]{2}{*}{ Blocks } & \multicolumn{3}{|c|}{ Standardized Values for indexing } & \multirow{2}{*}{$\begin{array}{c}\text { Transport } \\
\text { Disparity } \\
\text { Index } \\
\text { (DI } \text { TRANS }_{\text {TR }}\end{array}$} \\
\hline & $\mathrm{RD}$ & $\mathrm{BR}$ & RS & \\
\hline Matigara & 0.714 & 0.953 & 0.400 & 0.689 \\
\hline Maynaguri & 0.199 & 0.938 & 0.500 & 0.546 \\
\hline Mekhliganj & 0.321 & 0.984 & 0.300 & 0.535 \\
\hline Metiali & 0.374 & 0.984 & 0.300 & 0.553 \\
\hline Mirik & 0.155 & 0.375 & 0.100 & 0.210 \\
\hline Nagrakata & 0.082 & 0.984 & 0.500 & 0.522 \\
\hline Naxalbari & 0.156 & 0.969 & 0.100 & 0.408 \\
\hline Phansidewa & 0.026 & 0.922 & 0.100 & 0.349 \\
\hline Rajganj & 0.185 & 0.875 & 0.400 & 0.487 \\
\hline RangliRangliot & 0.041 & 0.766 & 0.200 & 0.336 \\
\hline Sitai & 0.300 & 0.656 & 0.100 & 0.352 \\
\hline Sitalkuchi & 0.512 & 0.438 & 0.200 & 0.383 \\
\hline Sukhiapokhri-Jorebunglow & 0.090 & 0.813 & 0.300 & 0.401 \\
\hline Tufanganj-I & 0.444 & 0.625 & 0.700 & 0.590 \\
\hline Tufanganj-II & 1.000 & 0.766 & 0.400 & 0.722 \\
\hline
\end{tabular}

\subsection{Spatial pattern of Multi-Dimensional Regional Disparity}

The Multi-dimensional disparity index (MDI) rank of different CD blocks and overall stage of socio-economic development of 37 blocks of 5 districts under Jalpaiguri division in West Bengal. The MDI includes education, health, socio-demography, employment, and economy and transport, presented in Table 8, and spatial variability illustrated in Figure 9. The value of MDI varies from 0.384 to 0.571 .

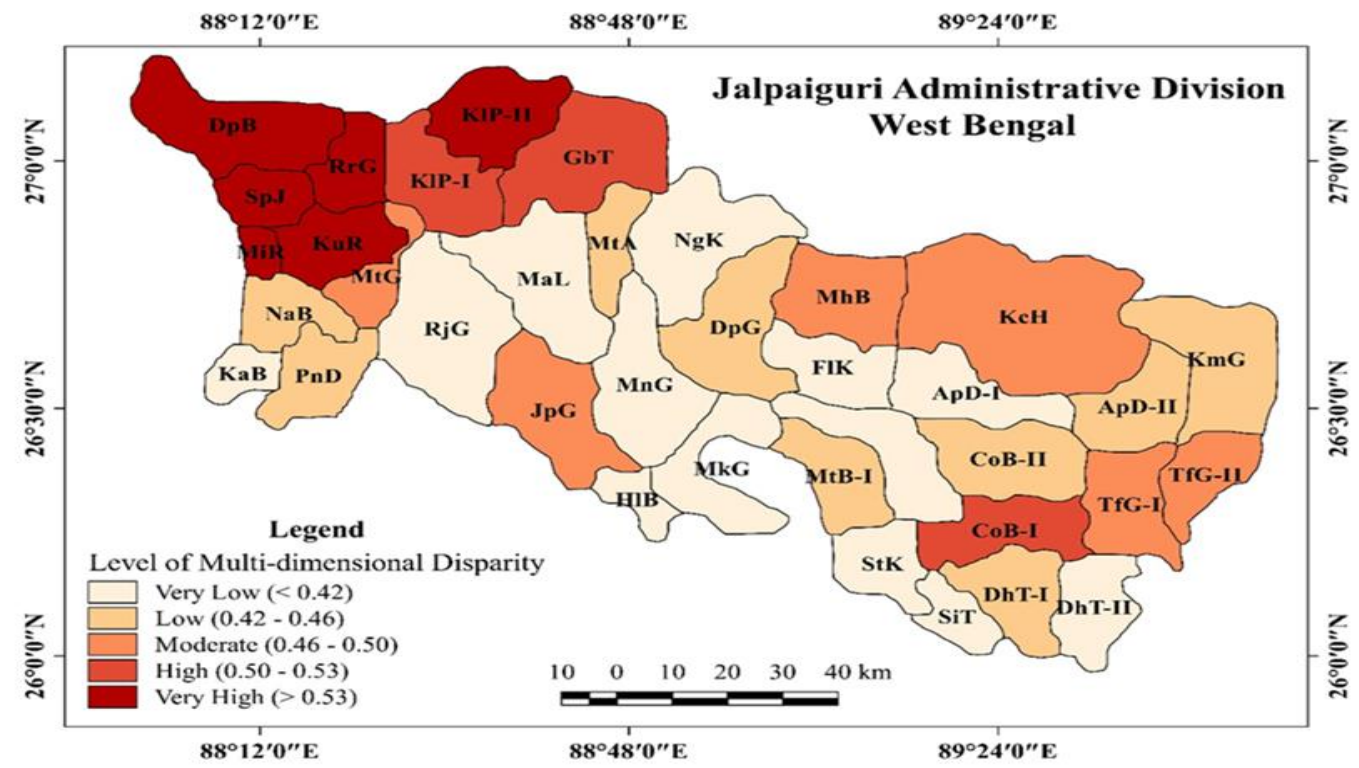

Figure 9. Inter-block spatial pattern of Multi-Dimensional Disparity Index 
Moreover, a total of six-block indicate a high distributional disparity of selected dimensions, where five blocks from Darjeeling district and one block from Kalimpong district. The blocks of Darjeeling-phulbazar, Sukihapokhri-jorebunglow, Rangli-rangit, Mirik, Kurseong, and Kalimpong-II are found to be very high disparity (Figure 9). These six blocks covering about 13.04 percent of the area and 7.02 percent of the population (Table 9). Further, three blocks (two from Kalimpong district and one from Cooch Behar district) are found to be a high disparity category, occupy about 9.23 percent of the area and 6.26 percent of the population. The moderate and low disparity categories include six and nine blocks, occupy about 18.36 percent and 24.47 percent of the area and 19.74 percent and 29.39 percent of the population, respectively. However, the majority of the blocks (13) score low disparity value in MDI. The blocks of Khairabari, Rajganj, Nagrakata, Maynaguri, Mal, Sitalkuchi, Sitai, Haldibari, Mekhliganj, Alipurduar-I, Falakata, Mathabhanga-II, Dinhata-II include under very low disparity category, covering about 34.90 percent of the area and 37.58 percent of the population (Table 9). The result indicates that Darjeeling and the newly formed Kalimpong district experienced a very high disparity in the five dimensions. Noteworthy that physiographic unsuitability, political instability, and the absence of major manufacturing industries are the major reason for the limited socio-economic development (Das, 2018). The study also found that the district of Darjeeling and Kalimpong performed better in transport development but experienced high inter and intra-regional disparity in other developmental factors. The results are also backed by the study of Das (2018); Som \& Mishra (2016) . The findings of Som \& Mishra (2016) illustrate that the northern part of West Bengal facing intense regional disparity caused the extortionate backwardness.

\subsection{Inter-district Disparity of Multi-Dimensional Development Aspect}

This section provides a valid underlying scenario on the inter-dimensional developmental disparity of five districts of the Jalpaiguri division (Figure 10). It helps to understand the overall issue more effectively. Figure 10 indicates that the district of Cooch Behar is moderately facing inter-dimensional disparity in regional development. However, the performance is worse in economic and transport development. The transport facilities are not relatively improved and equitably distributed to accelerate the growth of the district, which affects the economic growth. It also indicates a tendency of one-sided transport network development where the majority of the blocks of Cooch Behar, Jalpaiguri, and Alipurduar district experienced a lack of railway and bus terminus facility poor condition of roads. However, Darjeeling and Kalimpong district experienced satisfactory development in 
transport network development (Figure 10). The reason already mentioned in the above discussion. Further, Darjeeling and Kalimpong districts performed very poor in education, economic, and health aspects. The interesting scenario is that all the districts experience relatively equal development in the socio-demographic aspect. This means, sociodemographic factors not highly influenced the overall inter-district development. Moreover, the newly formed district Alipurduar is bitterly performed in all sectors of development compared to its counterparts.

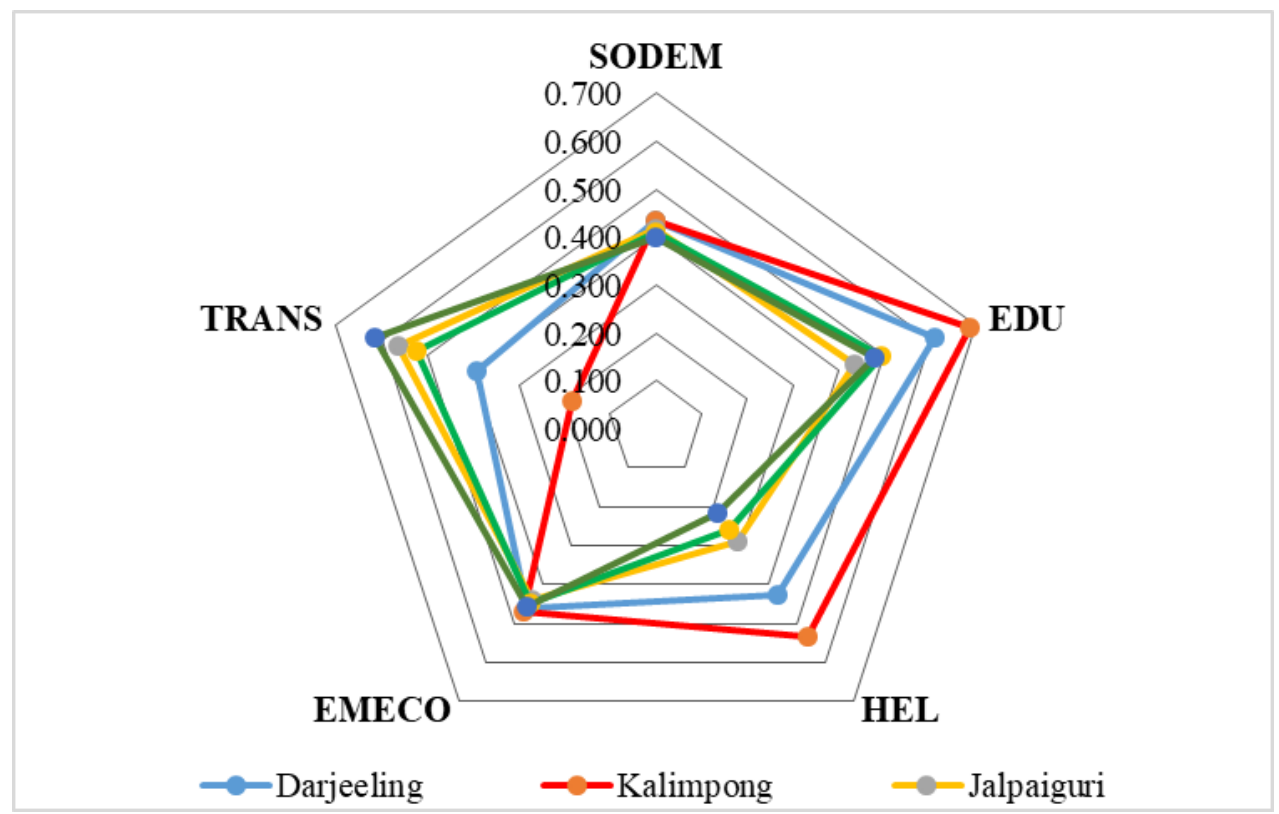

Figure 10. Inter-district comparison of selected multiple development disparity

The study of Kumar \& Rani (2019); Narin et al. (2017); Ohlan (2013) categorically found that the greater level of regional disparity has subsisted at national and state levels. The outcome of the present study affirms the previous findings. The study eventually corroborated that regional disparity is commonly found at the micro-level developmental unit in West Bengal. Yousuf et al. (2014) also studied the array of socio-economic development. In the study, they found inter-district disparity gradually backpedal the regional growth and reduced the course of human wellbeing (Yousuf et al., 2014). The result of Chotia \& Rao (2015) indicates that there is a close inter-linkage of economic development with region education, health, transport, energy, and agricultural performance. 
They even observed that poverty also emerged as an inference due to higher Intra and inter-regional imbalances in the distribution of infrastructural components. Regions of social growth and economic sustainability are highly acquainted with the sustainable existence of necessary socio-economic indicators (Chotia \& Rao, 2015; Dholakia, 2003; Novkovska, 2017; Ohlan, 2013). The study also established that there is high regional variation inhabited in the study area regarding the ordination of educational and health facilities at district and block level. The findings supported the study of Ahmed \& Hussain (2013). Further, the results confirmed the findings of Sam \& Chakma (2016) .

Table 8. Multi-dimensional Disparity Index (MDI) measured for each blocks of Jalpaiguri Administrative Division, West Bengal (Census of India, 2011a, b, c)

\begin{tabular}{|c|c|c|c|c|c|c|c|c|c|c|c|c|c|c|c|c|c|}
\hline \multirow{2}{*}{ Blocks } & \multicolumn{15}{|c|}{ Disparity Index values of selected dimensions } & \multirow[t]{2}{*}{ MDI } & \multirow[t]{2}{*}{ Rank } \\
\hline & DI $_{\text {SODEM }}$ & Rank & $\mathrm{SD}$ & $\mathrm{DI}_{\mathrm{EDU}}$ & Rank & $\mathrm{SD}$ & $\mathrm{DI}_{\mathrm{HEL}}$ & Rank & $\mathrm{SD}$ & $\mathrm{DI}_{\mathrm{EMECO}}$ & Rank & SD & $\mathrm{DI}_{\text {TRANS }}$ & Rank & $\mathrm{SD}$ & & \\
\hline Kharibari & 0.283 & 2 & IV & 0.394 & 4 & IV & 0.367 & 26 & II & 0.442 & 17 & III & 0.387 & 10 & III & 0.384 & 1 \\
\hline Phansidewa & 0.704 & 37 & $\mathrm{I}$ & 0.438 & 11 & III & 0.310 & 23 & III & 0.420 & 11 & III & 0.349 & 6 & III & 0.446 & 18 \\
\hline Naxalbari & 0.398 & 14 & III & 0.498 & 21 & III & 0.368 & 27 & II & 0.460 & 24 & II & 0.408 & 14 & III & 0.447 & 19 \\
\hline Matigara & 0.295 & 3 & IV & 0.433 & 9 & III & 0.475 & 32 & I & 0.532 & 33 & I & 0.689 & 33 & $\mathrm{I}$ & 0.465 & 25 \\
\hline Mirik & 0.270 & 1 & IV & 0.799 & 37 & I & 0.564 & 35 & I & 0.440 & 15 & III & 0.210 & 3 & IV & 0.550 & 34 \\
\hline Darjeeling-Pulbazar & 0.617 & 36 & I & 0.691 & 31 & I & 0.312 & 24 & III & 0.501 & 29 & II & 0.370 & 8 & III & 0.551 & 34 \\
\hline RangliRangliot & 0.447 & 29 & II & 0.692 & 32 & I & 0.580 & 37 & $\mathrm{I}$ & 0.454 & 21 & II & 0.336 & 5 & III & 0.552 & 35 \\
\hline Sukhiapokhri- & & & II & & & I & & & II & & & III & & & III & & \\
\hline Jorebunglow & 0.435 & 25 & & 0.783 & 36 & & 0.424 & 29 & & 0.430 & 14 & & 0.401 & 12 & & 0.562 & 36 \\
\hline Kurseong & 0.448 & 30 & II & 0.775 & 35 & I & 0.456 & 31 & I & 0.455 & 22 & II & 0.391 & 11 & III & 0.571 & 37 \\
\hline Kalimpong-I & 0.444 & 27 & II & 0.696 & 33 & I & 0.526 & 34 & I & 0.405 & 7 & III & 0.190 & 2 & IV & 0.521 & 30 \\
\hline Gorubathan & 0.414 & 19 & III & 0.609 & 30 & II & 0.571 & 36 & I & 0.524 & 32 & I & 0.271 & 4 & IV & 0.525 & 31 \\
\hline Kalimpong-II & 0.445 & 28 & II & 0.752 & 34 & I & 0.505 & 33 & I & 0.476 & 25 & II & 0.090 & 1 & IV & 0.547 & 32 \\
\hline Rajganj & 0.459 & 32 & II & 0.408 & 6 & III & 0.163 & 3 & IV & 0.446 & 20 & III & 0.487 & 17 & III & 0.395 & 3 \\
\hline Mal & 0.434 & 24 & II & 0.391 & 3 & IV & 0.308 & 22 & III & 0.413 & 9 & III & 0.603 & 28 & II & 0.409 & 6 \\
\hline Maynaguri & 0.418 & 20 & II & 0.515 & 24 & III & 0.204 & 6 & III & 0.338 & 1 & IV & 0.546 & 20 & II & 0.416 & 12 \\
\hline Nagrakata & 0.372 & 8 & III & 0.388 & 2 & IV & 0.440 & 30 & II & 0.440 & 16 & III & 0.522 & 18 & II & 0.417 & 13 \\
\hline Continued & & & & & & & & & & & & & & & & & \\
\hline
\end{tabular}




\begin{tabular}{|c|c|c|c|c|c|c|c|c|c|c|c|c|c|c|c|c|c|}
\hline \multirow{2}{*}{ Blocks } & \multicolumn{15}{|c|}{ Disparity Index values of selected dimensions } & \multirow{2}{*}{ MDI } & \multirow{2}{*}{ Rank } \\
\hline & $\mathrm{DI}_{\text {SODEM }}$ & Rank & SD & $\mathrm{DI}_{\mathrm{EDU}}$ & Rank & SD & $\mathrm{DI}_{\mathrm{HEL}}$ & Rank & SD & $\mathrm{DI}_{\text {EMECO }}$ & Rank & SD & $\mathrm{DI}_{\text {TRANS }}$ & Rank & $\mathrm{SD}$ & & \\
\hline Dhupguri & 0.455 & 31 & II & 0.437 & 10 & III & 0.307 & 21 & III & 0.405 & 6 & III & 0.601 & 25 & II & 0.427 & 14 \\
\hline Metiali & 0.324 & 5 & IV & 0.398 & 5 & IV & 0.374 & 28 & II & 0.533 & 34 & I & 0.553 & 22 & II & 0.429 & 15 \\
\hline Jalpaiguri & 0.444 & 26 & II & 0.490 & 19 & III & 0.226 & 10 & III & 0.499 & 27 & II & 0.629 & 10 & II & 0.459 & 23 \\
\hline Alipurduar-I & 0.410 & 17 & III & 0.455 & 13 & III & 0.209 & 8 & III & 0.430 & 13 & III & 0.454 & 16 & III & 0.406 & 5 \\
\hline Falakata & 0.392 & 12 & III & 0.473 & 18 & III & 0.205 & 7 & III & 0.374 & 3 & IV & 0.601 & 26 & II & 0.410 & 7 \\
\hline Kumargram & 0.403 & 16 & III & 0.527 & 26 & II & 0.260 & 15 & III & 0.444 & 19 & III & 0.405 & 13 & III & 0.439 & 17 \\
\hline Alipurduar-II & 0.398 & 15 & III & 0.554 & 28 & II & 0.271 & 18 & III & 0.417 & 10 & III & 0.451 & 15 & III & 0.448 & 20 \\
\hline Kalchini & 0.462 & 33 & II & 0.457 & 14 & III & 0.289 & 19 & III & 0.510 & 30 & II & 0.626 & 29 & II & 0.460 & 24 \\
\hline Madarihat-Birpara & 0.382 & 10 & III & 0.495 & 20 & III & 0.325 & 25 & II & 0.511 & 31 & $\mathrm{I}$ & 0.602 & 27 & $\mathrm{I}$ & 0.467 & 27 \\
\hline Sitai & 0.339 & 7 & III & 0.373 & 1 & IV & 0.307 & 20 & III & 0.500 & 28 & II & 0.352 & 7 & III & 0.386 & 2 \\
\hline Sitalkuchi & 0.382 & 9 & III & 0.454 & 12 & III & 0.252 & 14 & III & 0.405 & 8 & III & 0.383 & 9 & III & 0.396 & 4 \\
\hline Mekhliganj & 0.339 & 6 & III & 0.425 & 8 & III & 0.265 & 17 & III & 0.479 & 26 & II & 0.535 & 19 & II & 0.411 & 8 \\
\hline Mathabhanga-II & 0.412 & 18 & III & 0.411 & 7 & III & 0.238 & 11 & III & 0.424 & 12 & III & 0.668 & 32 & II & 0.412 & 9 \\
\hline Dinhata-II & 0.395 & 13 & III & 0.470 & 16 & III & 0.220 & 9 & III & 0.358 & 2 & IV & 0.652 & 31 & II & 0.412 & 10 \\
\hline Haldibari & 0.311 & 4 & IV & 0.505 & 22 & III & 0.261 & 16 & III & 0.378 & 4 & IV & 0.551 & 21 & II & 0.415 & 11 \\
\hline Dinhata-I & 0.419 & 21 & II & 0.465 & 15 & III & 0.170 & 4 & IV & 0.443 & 18 & III & 0.691 & 34 & I & 0.430 & 16 \\
\hline Mathabhanga-I & 0.427 & 23 & II & 0.471 & 17 & III & 0.203 & 5 & III & 0.565 & 37 & I & 0.577 & 23 & II & 0.456 & 21 \\
\hline Coochbehar-II & 0.487 & 35 & II & 0.548 & 27 & II & 0.140 & 2 & IV & 0.388 & 5 & IV & 0.718 & 35 & I & 0.457 & 22 \\
\hline Tufanganj-II & 0.391 & 11 & III & 0.524 & 25 & II & 0.246 & 12 & III & 0.459 & 23 & II & 0.722 & 36 & I & 0.466 & 26 \\
\hline Tufanganj-I & 0.421 & 22 & II & 0.507 & 23 & III & 0.247 & 13 & III & 0.547 & 35 & I & 0.590 & 24 & II & 0.473 & 28 \\
\hline Coochbehar-I & 0.468 & 34 & II & 0.588 & 29 & II & 0.048 & 1 & IV & 0.559 & 36 & I & 0.947 & 37 & I & 0.516 & 29 \\
\hline
\end{tabular}

Note : $\mathrm{SD}=$ Stage of Development; $\mathrm{MDI}=$ Multi-dimensional Disparity Index

\subsection{Inter-relationship among Multi-dimensional Domains of Regional Disparity}

The all-round development needs to minimize the relative disparity of all important sectors which directly interlinked with human development. For example, education and health are two critical components of accelerating the developmental process and providing a sustainable environment for human resource development. Furthermore, economy and employment highly depend on educational achievement, skills, training, and quality educational infrastructure. Moreover, the leaning on primary sectors of the economy leads to more prone towards livelihood vulnerability, namely poverty due to the low wage rate, variability of monsoonal rainfall, low productivity, crop damage, and 
associated lack of infrastructural facilities. It also concretizes the presence of poverty, and low human wellbeing hampers the overall developmental process. Transport build an inter-linkage to all other sector coupled with regional development. Hence, less disparity of interblock transport facilities eases the way to regional development. The table represents a correlation of selected dimensions with the overall regional disparity. The correlation shows Pearson bivariate correlation coefficient between education, health, socio-demography, economy, and employment and transport with MDI (Table 10). The person correlation coefficient indicates multi-dimensional regional disparity means development is strongly positive relation with education dimension, moderate positive relationship with health, socio-demography and economic dimension. However, transport has a very low negative relation with MDI, which indicates transport influences the overall development but in a limited appearance. The correlation coefficient of MDI with education and health is statistically significant with 99 percent (.01) confidence level, and transport is statistically significant with 95 percent (0.05) confidence level. The result further apprises that multi-dimensional regional development is largely influenced by education. The improvement in the educational and public health infrastructure positively influenced the inter-block development pattern and minimized the effect of disparity. The blocks performed better in the achievement of development where the educational infrastructure is quite satisfactory. Thereafter, it is high time to consolidate the quality educational facilities and grass root level health infrastructure, which automatically accelerate regional development. 
Table 9. Jalpaiguri Administrative Division: number of blocks, percentage of area and population under different category of disparity

\begin{tabular}{lccc}
\hline \multicolumn{1}{c}{ Level of Dimensional Disparity } & $\begin{array}{c}\text { Number of Blocks } \\
\text { Included }\end{array}$ & Area (\%) & Population (\%) \\
\hline Health Disparity & 2 & & \\
Very low & 11 & 5.92 & 9.09 \\
Low & 12 & 32.65 & 39.92 \\
Moderate & 5 & 9.13 & 34.14 \\
High & 7 & 15.48 & 8.58 \\
Very high & & & 8.27 \\
Educational Disparity & 14 & 40.08 & 41.17 \\
Very low & 12 & 32.06 & 37.92 \\
Low & 4 & 11.96 & 12.87 \\
Moderate & 3 & 8.32 & 3.68 \\
High & 4 & 7.57 & 4.35 \\
Very high & & & \\
Employment and Economic Disparity & 4 & 1018 & 13.12 \\
Very low & 8 & 24.27 & 26.68 \\
Low & 12 & 29.89 & 26.97 \\
Moderate & 7 & 21.48 & 17.39 \\
High & 6 & 14.18 & 15.84 \\
Very high & & & \\
Socio-demographic Disparity & 7 & 9.73 & 11.38 \\
Very low & 18 & 48.00 & 50.75 \\
Low & 10 & 34.78 & 32.35 \\
Moderate & 1 & 3.30 & 1.72 \\
High & 1 & 2.48 & 2.77 \\
Very high & & & \\
Transport Disparity & 3 & 5.72 & 2.55 \\
Very low & 11 & 26.22 & 19.52 \\
Low & 10 & 28.32 & 29.75 \\
Moderate & 12 & 3.67 & 4.43 \\
High & & & \\
Very high & & 2.86 & \\
\hline
\end{tabular}

Table 10. Pearson Correlations Coefficient of selected dimensions

\begin{tabular}{lllllll}
\hline & Health & Transport & Demography & Economy & Education & MDI \\
\hline Health & 1 & & & & & \\
Transport & $-.712 * *$ & 1 & & & & \\
Demography & -0.185 & -0.04 & 1 & & & \\
Economy & 0.103 & 0.114 & -0.025 & 1 & & \\
Education & $.503 * *$ & $-.487 * *$ & 0.172 & 0.005 & 1 & \\
MDI & $.556^{* *}$ & $-.360^{*}$ & 0.279 & 0.308 & $.919 * *$ & 1 \\
\hline
\end{tabular}

Note :** Correlation is significant at the 0.01 level.* Correlation is significant at the 0.05 level; MDI= Multidimensional Disparity Index.

\subsection{Socio-Economic Developmental Profile of Selected Parts of the Study Area}

Socio-economic development is defined as an impalpable transformation process to ameliorate society's existing social and economic status. Socio-economic development in a 
region depends on the people's performance in literacy, work participation, life expectancy, levels of employment, earning capabilities, population growth and infrastructural development (AEDA, 2013; Das, 1999; Sultana \& Aktar, 2016). Socio-economic development categorically manifested by the equitable distribution of resources (Ohlan, 2013; Wailerdsak \& Siengthai, 2017) and the compatible environment with the proper influence of regional institutions and governance for its embodiment (Talmaciu, 2014). In this context, a detailed discussion of inclusive resource profile, a brief overview of sociodemographic characteristics facilitates understanding the region's socio-economic development selected for the study. Herein, I am discussing the socio-economic profile of the three major districts. These are- Darjeeling (physiographically mountainous), Jalpaiguri (blending of hills, forest, and plain), and Coochbehar (mainly alluvial plains). This section excluded Kalimpong and Alipurduar districts. These districts were separated from Darjeeling and Jalpaiguri in February 2017 and June 2014, respectively. So, data availability is a significant limitation in the detailed discussion of the socio-economic characteristics of these two districts. To avoid this issue, I am elaborately reviewed the socio-economic developmental profile of Darjeeling, Jalpaiguri, and Coochbehar district.

\subsection{Cooch Behar District}

The district lies in the northeastern part of West Bengal, predominantly an agrarian district. The district stands 12th in terms of area (3887.00 square kilometers) in West Bengal, covering about 4.38 percent area in West Bengal. Cooch Behar district is the 17th populous district in the state, where a total population is 2.8 million (Census of India, 2011b). The density of population is 832 persons per square kilometer (ibid). As per the 2011 census, half of the population belongs to the scheduled caste (SCs) groups. The proportion of SCs population is highest in this district (ibid). The population of Scheduled Tribe (STs) is lowest in the district compared to the other counterparts of the state. The share of the urban population is increased from 9.1 percent (2001 census) to 10.3 percent ( 2011 census). The decadal (2001-2011) growth rate of the population was 13.7 percent, the same as the state average of population growth, i.e., 13.8 percent (ibid). The population enumeration summary shows that 12.2 percent of the population in the Cooch Behar district falls under the child population (age 0-6 years) category as per the definition provided by the Registrar General \& Census Commissioner India.

The sex ratio of the district is 942 females per 1000 males, lower than the West Bengal average sex ratio (Census of India, 2011b). Likewise, the sex ratio of SCs recorded as 
941, and the STs Sex ratio is 931. For instance, the interesting facts are that the district's child sex ratio (CSR) is declining. The CSR in 2001 recorded was 964, which drastically dropped and stood at 948 in 2011 (ibid). Further, the share of main workers is slightly increasing, from 78.0 percent (2001) to 78.6 (2011). As per the Indian Census, workers are classified as main and marginal workers based on the working days. These workers were termed as main workers who had engaged at work more than 183 days in a year. The work participation rate (WPR) of Cooch Behar district is 40 percent in 2011 (Census of India, 2011b). In the Cooch Behar district, about 32.34 percent of the population engaged in agriculture to sustain their livelihood, whereas 34.74 percent worked as agricultural labourers (ibid).

The scenario of literacy in the district has experienced lower improvising than the state average. Here, 74.8 percent are literate, which is lower than the state average literacy rate, i.e., 76.3 percent (Bureau of Applied Economic \& Statistics, 2013a; Census of India, 2011b). The gender gap in literacy stood at 12.22 percent. The National Family and Health Survey- 5 district facts shows that 75.7 percent of the female population (age six years and above) increased from the previous NFHS-4, i.e., 73.7 percent. Only 26.7 percent female population are complete their schooling with ten or more years (Ministry of Health and Family Welfare, 2020c). The NFHS-5 (2019-20) examines 98.2 percent and 99.3 percent of the population of the surveyed household in the Cooch Behar district living with electricity and improved drinking water source. More than 75 percent population use an improved sanitation facility (ibid). Despite that, only 25.7 percent of households using clean fuel for cooking. The survey shows that about 64 percent of households are left to cover under health insurance/financial schemes. The NFHS-5 findings revealed that the trend of institutional delivery is increasing in the district. During NFHS-4, the instance of institutional delivery was recorded as 81.2 percent, which has positively improved and recorded 93.0 percent in NFHS-5 (ibid). The majority ( 92.5 percent) of the birth is attended by the trained personals and skilled health workers. Child vaccination is a crucial aspect under the target of a universal immunization programme. In the Cooch Behar district, 94.2 percent of children age under 12-23 months are fully vaccinated. Further, 98.5 percent of children (12-23 months) received BCG, 97 percent of children received the polio vaccine, and 94.2 percent of children have a DPT vaccine (ibid).

\subsection{Jalpaiguri District}

The Jalpaiguri district is located in the northernmost part of West Bengal. The district is majorly rural and agrarian. The undivided Jalpaiguri district covers about 7.02 percent of 
the area of the West Bengal state, which sustains about 4.24 percent of the population. The population density of the district is 622 people per square kilometer, lower than the state average (Census of India, 2011a). As per 2013-2014, the total cropped area is recorded about 336.02 thousand hectares (Bureau of Applied Economic \& Statistics, 2013c). In case of total cropped area, 43.34 percent of cultivable area are under irrigation facilities (ibid). Tea is a primary natural resource in the district, where the majority of the scheduled tribe population worked in the tea garden as informal labour (Sarkar, 2017). However, the yield rate of paddy is 2270 kilogram per hectares. In the district, merely 39 percent population are engaged in productive work. The majority of the population (72.62 percent) lived in rural areas, while only 27.39 percent population lived in urban areas (Census of India, 2011a). The interesting fact is that the Nagrakata block is fully occupied by rural settings. There is no trace of urban characteristics. The block is also concentrated by the scheduled tribe population. Literacy scenario is a concern for Jalpaiguri district. Here, 73.25 percent population are recorded as literate, means able to read and write (Census of India, 2011a). The literacy rate is much lower than the state and national average. The gender gap in literacy is 13.72 (ibid). As per 2013-2014 data, about 22889 Micro and Small Scale Enterprises (MSSE) were recorded in the district. Further, 893 co-operative societies function with a working capital of about 5.88 crores (Bureau of Applied Economic \& Statistics, 2013c).

The NFHS-5 district data fact shows that majority of the population is covered under the facility of electricity and improved drinking water (Ministry of Health and Family Welfare, 2020b). The situation is worse in the use of clean cooking fuel. Further, 73.2 percent population use proper sanitation facilities. However, the coverage of improved sanitation facilities drastically improved in the district, from 51 percent to 73.2 percent (ibid). A significant proportion of the population (64.2 percent) is not covered under any health insurance/financial scheme. The district has recorded 95.8 percent of institutional delivery, whereas 97.7 percent of delivery is handled by trained health workers. The programme of universal vaccination also achieved the target at a greater pace. Here, 87.9 percent of children (12-23 months) are vaccinated, and the number increases compared to the NFHS-4 findings (ibid).

\subsection{Darjeeling District}

Darjeeling district is located in the northernmost part of the state of West Bengal. The district lies in the foothills of the Himalayas, comprise a scenic beauty for major tourist attractions. The district is also famous for Darjeeling tea, mainly used as an export item. 
Previously, the district comprised 12 blocks. However, on February 14, 2017, the Kalimpong subdivision (3 blocks) was separated and designated district status. The area of the undivided Darjeeling district is 3149 square kilometers. The population density is 586 person per square kilometer (Census of India, 2011c). In the Darjeeling district, about 60.58 percent population lived in rural settings, and the rest of the population lived in urban areas (ibid). The following district is very scare in terms of agricultural land. Only 135.47 thousand hectares of land are designated as cropped area, whereas only 7.78 percent area is under irrigation facilities (Bureau of Applied Economic \& Statistics, 2013b). The literacy scenario is much appreciating, and it is greater than the state and national average. Further, the male-female literacy difference is also higher in the district (Census of India, 2011c).

In the Darjeeling district, about 80 tea gardens are registered, majority of the population worked in the tea garden to survive in their daily livelihood (Happy Earth Tea Company, n.d.). The National Family and Health Survey- 5 district facts shows that 78.3 percent of the female population (age six years and above) attended school slightly increased from the previous NFHS-4, i.e., 77.0 percent (Ministry of Health and Family Welfare, 2020a). Only 41.3 percent female population are complete their schooling with ten or more years. The NFHS-5 (2019-20) examines 98.2 percent and 90.8 percent of the population of the surveyed household in the Darjeeling district living with electricity and improved drinking water source (ibid). Moreover, 83 percent population use an improved sanitation facility. Despite that, only 68.8 percent of households using clean fuel for cooking. The survey shows that about 76 percent of households are left to cover under health insurance/financial schemes (ibid).

\section{Conclusion}

The blocks of Khairabari, Darjeeling-Pulbazar, Rngli-rangit, Mirik, Kurseong, Kalimpong I \& II are found to be high regional imbalances in the development of education, health, employment, and economy. Likewise, the block Coochbehar, it was found to be highly skewed differences in transport development compare to the other counterparts. The engrossing findings is that the blocks situated in high elevation facing low development in all dimension except transport. Because transport is a major way to carried out tourism activities, the people of these blocks predominantly engaged in the tourism related activities to subsist their daily livelihood. In addition to this, the blocks of Darjeeling and Kalimpong district mainly underdeveloped, caused by the physiographic unevenness, landlessness, lack of irrigation facilities, absence of manufacturing industries, closure of tea gardens, the low 
opportunity of livelihood diversification, and political instability. The Gorkhaland movement, Kamtapuri movement, and Greater Cooch Behar movement are significant cause-effect association with the stagnant regional development in north Bengal. In addition to these, in $\mathrm{JAD}$, the five districts have only one Higher Education University and medical college, which creates huge uncertainty in the access to better healthcare facilities and acquiring quality education. Moreover, it observed that the high disparity district all not facing high disparity in all variables of the selected dimensions. Categorically some variables of a particular dimension are resultant high and/or moderately high levels of disparity. In addition to these, to speed up the development process, the government formed new districts like Kalimpong and Alipurduar, which concisely focused on regional development, enhancing governance, and implementing government schemes and policies. However, for an inclusive regional development purpose, the government should focus on priority-based development with a targeted agenda. Also, the government must ensure the equitable distribution of infrastructural facilities, where the development is slow down.

\section{Conflicts of Interest}

The author declares that there is no conflict of interest with any financial, personal, other people or organizations related to the material in this study.

\section{References}

Adu, D. T., Kuwornu, J. K., Anim-Somuah, H., \& Sasaki, N. (2018). Application of livelihood vulnerability index in assessing smallholder maize farming households' vulnerability to climate change in Brong-Ahafo region of Ghana. Kasetsart Journal of Social Sciences, 39(1), 22-32. https://doi.org/10.1016/j.kjss.2017.06.009.

Agricultural \& Environmental Data Archive. (2013). Socio-economic development. Retrieved from http://www.environmentdata.org.

Ahmed, N. (2013). Identification of micro regional disparities in the level of development in the rural areas: A case study of Malda District of West Bengal (India). International Journal of Management and Social Sciences Research, 2(5), 37-45.

Akhtar, R., \& Izhar, N. (1986). The spatial distribution of health resources within countries and communities: Examples from India and Zambia. Social Science \& Medicine, 22(11), 1115-1129. https://doi.org/10.1016/0277-9536(86)90178-4.

ALC India. (2018). Basic Module for Promotion of Sustainable Livelihoods Practitioners Guide. New Delhi : National Level Training Programme.

Banerjee, S. (1992). Disparities in development of socio-economic infrastructure in rural areas of selected district of Uttar Pradesh. Geographical Review of India, 54(1). 
Banu, N., \& Biswas, B. (2021). Role of international border on healthcare access in West Bengal, India: A geographical analysis. GeoJournal. Published. https://doi.org/10.1007/s10708-021-10411-8.

Barman, S. (2020). Appraisal of Pattern of Micro-Regional Disparity in Socio-economic Development: Evidences from the Districts of North Bengal, India, Geography in the 21st Centuary Emerging Issues and the way Forward (pp. 186-202). New Delhi : Namya Press.

Bera, S., Das, A., \& Mazumder, T. (2019). A multi-objective framework for multidimensional vulnerability assessment - Case of a coastal district of West Bengal, India. Journal of Environmental Management, 249, 109411. https://doi.org/10.1016/j.jenvman.2019.109411

Bhandari, L. \& Chakraborty, M. (2015). Spatial Poverty in West Bengal. Retrieved from https://www.livemint.com/.

Biriescu, S., \& Babaita, C. (2014). Rural Education, an Important Factor of Regional Development in the Context of Local Government Strategies. Procedia - Social and Behavioral Sciences, 124, 77-86. https://doi.org/10.1016/j.sbspro.2014.02.462.

Biswas, B. (2016). Regional Disparities Pattern of Literacy in Rural and Urban area of West Bengal, India. Global Journal of Multidisciplinary Studies, 5(7), 105-112.

Bose, A., Mondal, A., \& Chowdhury, I. R. (2020). A Study on Inter-block level Regional Disparity Analysis of Uttar Dinajpur District, West Bengal. In R. Sarkar (Ed.), Geography in the 21st Century Emerging Issues and the way Forward (pp. 225-248). New Delhi : Namya Press.

Brandt, W. (1980). North-South: A Programme for Survival. London: Pan Books.

Braveman, P. (2014). What are Health Disparities and Health Equity? We Need to Be Clear. Public Health Reports, $129 \quad$ (1), 58. https://doi.org/10.1177/00333549141291s203.

Bureau of Applied Economic \& Statistics (2013a). Cooch Behar District Statistical Handbook 2010 \& 2011. Retrieved from http://www.wbpspm.gov.in/.

Bureau of Applied Economic \& Statistics (2013b). Darjeeling District Statistical Handbook 2013. Retrieved from http://www.wbpspm.gov.in/.

Bureau of Applied Economic \& Statistics (2013c). Jalpaiguri District Statistical Handbook 2013. Retrieved from http://www.wbpspm.gov.in/.

Cai, F., Wang, D., \& Du, Y. (2002). Regional disparity and economic growth in China: The impact of labour market distortions. China Economic Review, 13(2-3), 197212. https://doi.org/10.1016/S1043-951X(02)00072-X.

Census of India (2011a). District Census Handbook:Jalpaiguri Village and Town Directory (Part XII-A). Retrieved from https://censusindia.gov.in/.

Census of India (2011b). District Census Handbook: Koch Bihar Village and Town Directory (Part XII-A). Retrieved from https://censusindia.gov.in/. 
Census of India (2011c). District Census Handbook: Village and Town Directory (Part XIIA). Darjiling Directorate of Census Operations West Bengal. Retrieved from https://censusindia.gov.in/.

Chotia, V., \& Rao, N. (2015). Examining the interlinkages between regional infrastructure disparities, economic growth, and poverty: A case of Indian states. Economic Annals, 60(205), 53-71. https://doi.org/10.2298/eka1505053c.

Das, A. (1999). Socio-economic development in India: a regional analysis. Development and Society, 28(2), 313-345.

Das, A. (2017). Re-examining human development in West Bengal, India. Journal of Social and Economic Development, 19(2), 341-364. https://doi.org/10.1007/s40847-0180054-6.

Das, J. (2018). Regional Disparity in the Level of Development in West Bengal: A Geographical Analysis. Indian Journal of Regional Sciences, 1(1), 53-63.

Dey, K. S. (2015). Regional inequality of West Bengal: A District level study. Bangladesh Development Studies, 38(1), 101-117.

Doolakia, R. H. (2003). Regional disparity in economic and human development in India. Economic \& Political Weekly, 38(39), 4166-4172.

Drewnowski, J. (1972). Social indicators and welfare measurement: Remarks on methodology. The Journal of Development Studies, 8(3), 7790. https://doi.org/10.1080/00220387208421413.

Dutta, A. (2017). Modified Poverty Index of West Bengal: A human development approach. International Journal of Multidisciplinary Research and Development, 4(10), 43-50.

Kumar, N., \& Rani, R. (2019). Regional Disparities in Social Development: Evidence from States and Union Territories of India. South Asian Survey, 26(1), 127. https://doi.org/10.1177/0971523118825388.

Kwatiah, N. (2021) Main Causes of Regional Imbalances in India. Retrieved from https://www.economicsdiscussion.net.

Lakshmi, T. S., \& Sahoo, D. (2013). Health Infrastructure and Health Indicators: The Case of Andhra Pradesh, India. IOSR Journal of Humanities and Social Science, 6(6), 2229.

Li, B., Gao, S., Liang, Y., Kang, Y., Prestby, T., Gao, Y., \& Xiao, R. (2020). Estimation of Regional Economic Development Indicator from Transportation Network Analytics. Scientific Reports, 10, 2647. https://doi.org/10.1038/s41598-020-59505-2.

Miao, J., \& Wu, X. (2016). Urbanization, socio-economic status and health disparity in China. Health \& Place, 42, 8795. https://doi.org/10.1016/j.healthplace.2016.09.008.

Ministry of Health and Family Welfare (2020a).National Family Health Survey-5 2019-2020 District Fact Sheet Darjeeling, West Bengal. Retrieved from http://rchiips.org.

Ministry of Health and Family Welfare (2020b).National Family Health Survey-5 2019-2020 District Fact Sheet Jalpaiguri, West Bengal. Retrieved from http://rchiips.org. 
Ministry of Health and Family Welfare (2020c). National Family Health Survey-5 2019-2020 District Fact Sheet Koch Bihar, West Bengal. Retrieved from http://rchiips.org.

Mishra, S. K., \& Gaikward, S. B. (1979). Impact of economic development on welfare and living condition of people of Madhya Pradesh (An inter-district Case studies). Indian Journal of Regional Sciences, 11(1), 25-36.

Narain, P., Sharma, S. D., Rai, S. C., \& Bhatia, V. K. (2007). Statistical evaluation of Socioeconomic development of different states in India. Journal of the Indian Society of Agricultural Statistics, 61(3), 328-325.

Novkovska, B. (2017). Regional Development Disparities and their connection with hidden economy. UTMS Journal of Economics, 8(2), 151-158.

Ohlan, R. (2013). Pattern of Regional Disparities in Socio-economic Development in India: District Level Analysis. Social Indicators Research, 114(3), 841873. https://doi.org/10.1007/s11205-012-0176-8.

Pal, G. K. (1995). Regional disparities in economic development: An Inter-district empirical study of the state of West Bengal. ArthasVijnana, 3, 276-296.

Rao, B. S., \& Gupta, P. V. (2006). Low Female Literacy: Factors and Strategy. Australian Journal of Adult Learning, 46(1), 85-95.

Rekha, R. S., Wajid, S., Radhakrishnan, N., \& Mathew, S. (2017). Accessibility Analysis of Health care facility using Geospatial Techniques. Transportation Research Procedia, 27, 1163-1170. https://doi.org/10.1016/j.trpro.2017.12.078.

Sam, K., \& Chakma, D. N. (2016a). An Inter-Block Level Analysis of Regional Disparity in the Youngest Alipurduar District of West Bengal. Space and Culture, India, 3(3), 10-21. https://doi.org/10.20896/saci.v3i3.159.

Sam, K., \& Chakma, D. N. (2016b). An Inter-Block Level Analysis of Regional Disparity in the Youngest Alipurduar District of West Bengal. Space and Culture, India, 3(3), 10-21. https://doi.org/10.20896/saci.v3i3.159.

Sarkar, B. C. (2017). Socio Economic status of tribal people in Mal Subdivision of Jalpaiguri District West Bengal a geographical analysis. Doctoral Thesis. University of North Bengal, West Bengal, India. Retrieved from http://hdl.handle.net/10603/214654.

Sharma, A. (2012). Inter-state Disparities in Socio-economic Development in North East Region of India. Journal of Agricultural Science, 4(9). https://doi.org/10.5539/jas.v4n9p236.

Som, K. S., \& Mishra, R. P. (2016). Regional disparity in the level of development, West Bengal. The Decan Geographer, 54(1), 23-34.

Sultana, S., \& Aktar, N. (2016). Regional imbalance in the levels of socio-economic development: A case study of Malda district, West Bengal. NEHU Journal, 14(1), 69-86.

Talmaciu, M. (2014). Study on the Relationships between Institutions, Governance and Leadership and Regional Development Policy in Romania. Procedia Economics and Finance, 15, 1281-1288. https://doi.org/10.1016/s2212-5671(14)00589-9. 
Wailerdsak, N., \& Siengthai, N. (2017). Chapter 10 - Business Networks in Thailand: Import Substitution, Export Oriented, and Expansion in AEC. In J. Nolan, C. Rowley, \& M. Warner (Eds.), Business Networks in East Asian Capitalisms (pp. 211-233). Elsevier. https://doi.org/10.1016/B978-0-08-100639-9.00010-4.

Yousuf, T., Yousuf, T., \& Raja, T. A. (2014). Regional Disparities in Socio-Economic Development-A Statistical Evaluation of Kashmir Valley,J\&K. European Academic Research, 1(10), 3731-3744. 